\title{
A FENNTARTHATÓ FEJLÓDÉS ÉRTÉKEI ÉS AZ EGÉSZSÉGTUDATOS ÉLETSTÍLUS ELEMZÉSE KÖZÉPISKOLÁS DIÁKOK KÖRÉBEN
}

\author{
$\longrightarrow$ \\ ANALYSIS OF THE VALUES OF SUSTAINABLE DEVELOPMENT AND THE HEALTH \\ CONSCIOUS LIFESTYLE AMONG SECONDARY SCHOOL STUDENTS

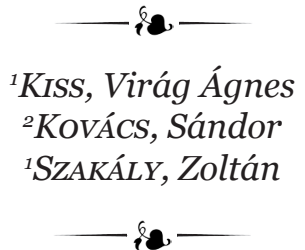

${ }^{1}$ Debreceni Egyetem, Gazdaságtudományi Kar, Marketing és Kereskedelem Intézet (University of Debrecen, Faculty of Economics and Business, Institute of Marketing and Commerce) ${ }^{2}$ Debreceni Egyetem, Gazdaságtudományi Kar Ágazati Gazdaságtan és Módszertani Intézet (University of Debrecen, Faculty of Economics, Institute of Sector Economics and Methodology) H-4032 Debrecen, Böszörményi út. 138. e-mail: kiss.virag.agnes@econ.unideb.hu

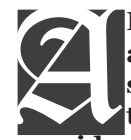

Health, together with the social- and natural environment has become the most important and core value recently. The current research would like to explore the presence of sustainable development related values and the elements of health consciousness among the consumption behaviour of secondary school students. The aim of the first part is to provide an overview of conscious consumption, sustainable development and the literal researches connected to this particular generation. In the second part of the work, we present the results of a research made between April 2015 and 2016 involving 1002 students of 13 institutions. During the selection, we kept in mind to choose institutions of all different profiles (human, sport, art, general) and different types (grammar school, vocational high school, technical school). During creating the questionnaire, the basis of the questions and statements since was the consumption trends that can be found in the literature sources as well. We analysed the data with the help of frequency indicators together with factor- and cluster analyses. During the primary examinations, we identified five factors that were created along with the values of the following behaviours: trend-following individualistic, health- and environmental conscious, authentic patriot, altruisticethical and business ethical. With the help of them, we could name four well-divided groups after the cluster analysis, where the values of the created factors can be realised at different rates. The groups were the Trend-avoiding Conscious, the Responsibility-blamers, the Passive "freshmen" and the Conscious individualists. The first group can be related to the trends of voluntary simplicity, whereas the fourth segment shows a strong similarity to the values of the LOHAS consumer group. These groups - and their different socio-demographic features - raise the attention to the fact that knowledge, messages and examples-to-follow are worth conveying with a differentiated marketing communicational strategy. This secondary school generation undertakes their connection to the particular sustainable and health conscious values, and - at least in a theoretical field - the majority of the students admit their responsibility in shaping the environment and their own health. In the case of conscious consumption, the peculiarities of this generation (digital, "Always on" generation) demand a quite new communicational approach in transporting messages and possibilities of act. 


\section{BEVEZETÉS - INTRODUCTION}

Egy olyan környezet megteremtése, amelyben a jövő generáció egészségesen és cselekedetei környezeti hatásának ismeretével nőhet fel minden társadalom kiemelt fontosságú feladata. Fogyasztási szokásaink már gyermekkorban kezdenek kialakulni, fogékonyságunk a változatosságra, tudatosságra már ekkor tetten érhető. Továbbá az elmúlt 20-25 évben a fiatalok önálló társadalmi mezőként (szegmensként) jelennek meg, melynek oka, hogy jóval nagyobb befolyással vannak saját életükkel és életvitelükkel kapcsolatos döntéseik meghozására (VASKOVICS, 2000). A tudatos fogyasztás mind a fogyasztók, mind a kutatók körében egyre fontosabb kérdéssé válik, bár konkrét megfogalmazása kapcsán találhatunk eltéréseket. A fenntartható fejlődés és annak fogyasztói lehetőségei kapcsán is erős szakmai vita alakult ki az elmúlt években, hiszen a kutatók a saját maguk által preferált területet helyezik a középpontba. A legtöbb kutatás mégis a természeti környezetre való fokozott odafigyeléssel ért egyet, viszont a humán értékek és érdekek védelmével is összefüggésbe hozzák az ehhez kapcsolódó fogyasztói attitűdöket.

A mai középiskolások a jelen és a távoli jövő fogyasztói generációja, akiknek attitűdjei és cselekvési hajlandósága ezáltal kiemelt fontosságú mind társadalmi, mind gazdasági és környezeti szinten. Ezek a már most is vásárlóerővel bíró fiatalok egy-egy döntésükhöz szükséges ismereteiket - digitális bennszülött létük miatt - már akár pár óra alatt összegyüjtik és mérlegelik. Az információgyüjtés és racionális döntés természetesen - a felnőttekhez hasonlóan - nem jellemzi a teljes középiskolás sokaságot, ezért is tartottuk fontosnak, hogy körükben is megismerjük az egyes szegmenseket, melyek karakterisztikáit feltárva fogalmazunk meg javaslatokat a tudatos fogyasztói mozgalomba való bevonásukra.

\section{SzAKIROdALMi ÁTTEKINTÉS - LITERATURE REVIEW}

\subsection{Tudatosság - Consciousness}

A tudatos fogyasztóvá válás egy hosszú és sokoldalú folyamat, melyben az egyes termékek, szolgáltatások és maga a piac megismerése, megértése fontos szerepet játszik. Ezen keresztül lehet képes az egyén adekvát módon viselkedni, a saját és a közösség érdekeit érvényesíteni úgy, hogy a fenntartható fejlődés értékeit is figyelembe veszi (ÁDÁM, 2001). A szakirodalom jellemzően két típusú tudatos fogyasztást különböztet meg: az egyéni tudatos és a társadalmilag felelős fogyasztást (DUDÁS, 2011). Egyéni szinten megjelenik a minőség-, az ár-, a márka-, az érték-, a fogyasztói jogok, a pénzügyi, az egészség- és táplálkozástudatos fogyasztói forma (DUDÁS, 2011; KISS, 2015). A hazai szakirodalomban több esetben nemzetközi mintára a társadalmilag felelős csoportokat az alábbi irányzatok mentén különítették el a kutatók: környezettudatosság, etikus fogyasztás, önkéntes egyszerűség, eredettudatosság, etnocentrikus fogyasztás, méltányos kereskedelem és LOHAS (KOCSIS, 2001; MALOTA, 2003; SZABÓ, 2006; GULYÁS, 2007; TÖRŐCSIK, 2007; KELEMEN, 2010; DUDÁS, 2011; HOFMEISTER-TÓTH, KELEMEN és PISKÓTI, 2011; RÁCZ és HORVÁTH, 2011; KOVÁCS, 2013).

A tudatosság rutinná válásához viszont szükséges az adekvát környezet is, hiszen a legtöbben egyedül érzik magukat a tudatos magatartásban, ezért el is hagyják azt, vagy egyszerűen a „Más se csinálja!” felkiáltással hárítják el magukról a felelősséget (SORON, 2010). Továbbá akár környezet-, akár egészségtudatosságról legyen szó, a probléma a legtöbb esetben a pénzhiány és a berögződött szokásokban, gondolkodás mintázatokban van (NAGY, 2011). Több kutatásból az derül 
ki, hogy az embereket annyi hatás éri, hogy a biztosnak vélt vásárlói magatartásukat, elhatározásukat vagy az önmaguk által meghatározott anyagi kultúrát akaratlanul is felülírják vásárlási döntéseikkel. Ezek a hatások lehetnek nüansznyi ellentmondások, esetleg a különböző élettereinkben elvárt identitás különbségekből fakadóak. Ezekben a helyzetekben állandó kompromisszumkötésekre kényszerülhet a fogyasztó a minőség, az érték, az etikusság (SLATER és MILLER, 2007) vagy az ár tényezőinek kereszttüzében. Az ekkor felmerülő disszonancia csökkentése és a rugalmasság növelése fontos (SZMIGIN, CARRIGAN és MCEACHERN, 2009), hiszen a kudarcélmény negatívan befolyásolhatja a későbbi újrapróbálkozásaikat. Továbbá a vásárlás inkább közösségi élmény, tapasztalás, mint individuális (CARU-COVA, 2003; BARNETT, 2007), így a közösségi hatás közvetve vagy közvetlenül pozitív és negatív irányba befolyásolhatja a tudatos választásunkat. Ezért is lehet nagyon fontos, hogy a tudatos fogyasztás közös ügy legyen, hiszen szociális környezetünk erősen determinálja választásainkat az élet minden területén.

További akadály, hogy a fogyasztók egy része a helyi önkormányzatoktól és az államtól várja, hogy a környezet állapotáról és védelméról gondoskodjanak, és csupán 27\%-nál jelenik meg az állampolgárok és a családok felelőssége ebben a kérdésben (VALKÓ, 2003).

\subsection{Egészség és környezet - Relationship between Health and Environment}

Az egészségtudatos és a fenntartható fejlödés értékei több kisebb életviteli területre is kiterjednek, illetve egymásra egyértelműen hatással vannak. Egészséges környezet nélkül nem beszélhetünk természetesen fenntartható egészségről. A környezet állapota komoly hatással van a humán egészségre - különösen a gyermekekre (VITRAI és VOKÓ, 2006; NEIRA et al., 2008), hiszen többek között a levegő-, a föld- vagy a vízszennyezés közvetve vagy közvetlenül súlyos élettani károkat okozhat. Továbbá kiegyensúlyozott társadalmi környezet és jólét nélkül sem valósulhat meg a fenntartható egészség (MCGINNIS, 2002; KERK és MANUEL, 2008; KISS, 2015). Ezt megerősíti a WHO (1946) definíciója is, mely nem a be- tegség hiányában látja az egészséget, hanem a teljes testi, lelki és szociális jóllét állapotában. Így azt mondhatjuk, az egészség egyaránt rendelkezik objektív és szubjektív dimenzióval. BAGDY (2010) szerint az egészségtudatosság kulcsa abban rejlik, hogy az egyének vállalják saját magukért és egészségükért a felelősséget, és tesznek annak megőrzéséért és egyensúlyban tartásáért az egészség minden szintjén. HARRIS és GUTEN (1979) az egészségmagatartás esetében összetett, egymástól függő, illetve egymást befolyásoló tényezőkről beszélnek, amelyek közül az általunk vizsgált korosztályban a testmozgás, a táplálkozás vagy a rizikómagatartás élvez kitüntetett szerepet (HARRIS és GUTEN, 1979 idézi SZAKÁLY, 2008).

Az általános egészségnek kedvez a mai fogyasztói társadalom hozzáállása, hiszen az egészséges életmóddal kapcsolatos termékek és szolgáltatások kereslete növekedett (GAÁL et al., 2011; GFK és TÁRKI, 2012; FÜZESI és VARGA, 2014). A gazdasági fejlődésért felelősnek tartott Kondratyev-ciklust is napjainkban az egészségiparhoz kötik, mely már az egészség megőrzésére, és nem a betegség kezelésére fókuszál (NEFIODOW, 1999 idézi KALÓ, 2007). Bár a környezeti kérdésekhez való hozzáállás a magyar fogyasztók körében is egyre pozitívabb, de a személyes áldozatvállalási hajlandóság alacsonynak mondható (FÜZESI és TISTYÁN, 1998).

\subsection{Fenntartható fejlődés értékei - Values of Sustainable Development}

Ahhoz, hogy definiálni tudjuk a fenntartható fejlődéshez kapcsolódó értékeket, először annak fogalmi hátterét kell megismerni. A fenntartható vagy fenntarthatóság kifejezések már annyira egybeforrottak a fenntartható fejlődés globális eszméjével (LÁNG, 2001), hogy önmagukban is jelölik a környezetbarát, környezetkímélő, energiatudatos, környezettudatos, bio-öko, zöld jelzőket, illetve hatásos hívószóként használják azokat a vállalatok különböző marketing célokra. Magát a fenntartható fejlődés fogalmát először BROWN (1981) publikálta a társadalom fenntarthatóságáról szóló múvében, mely a természeti erőforrások romlását a népességnövekedéssel 
és a természeti erőforrások felhasználásával hozta összefüggésbe (CSETE, 2012). A könyv kitér továbbá minden korábbi kutatásban felmerült veszélyre, és a fenntartható társadalomban látja a kérdés nyitját (BROWN, 1981). A legtöbb tudományos diskurzust az a kettősség hozza a fenntartható fejlődéssel kapcsolatba, hogy a gyenge vagy az erôs fenntarthatóság elvét veszik alapul a célok kitüzésénél (SZLÁVIK, 2002, 2014; KEREKES, 2006; FLEISCHER, 2007; MÁLOVICS és BAJMÓCY, 2009; CSETE, 2012). A legutóbbi fenntartható fejlődésről folytatott ENSZ Világcsúcson már a korábbiakban is megfogalma- zott akadály, a szegénység került a középpontba a környezetvédelem mellett. Ez az új agenda 2030-ig szóló együttmúködést vár el 17 közös cél mentén (1. ábra) (ENSZ, 2015; FARKAS, 2015). A 17 fenntartható fejlődést szolgáló cél tanulmányázásából kiderül, hogy a környezetvédelem mellett a szociális és gazdasági kérdések is nagy számban jelennek meg, de a környezet kérdése kiemelten kezelt.

Saját kutatásunkban olyan értékeket jelenítettünk meg, melyek az ENSZ átfogó, fenntartható fejlődést segítő céljaival egyeztethetőek össze.
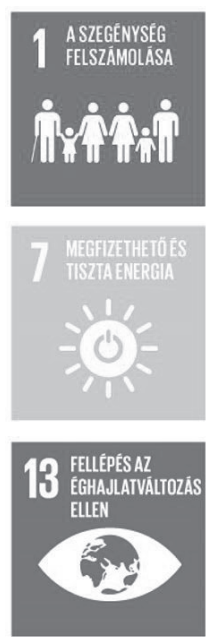

1. ÁBRA
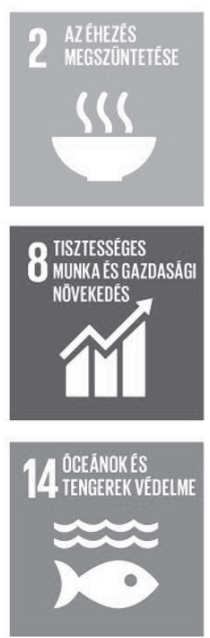
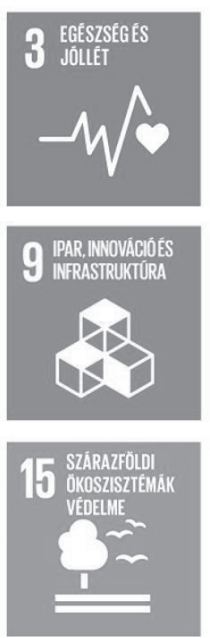
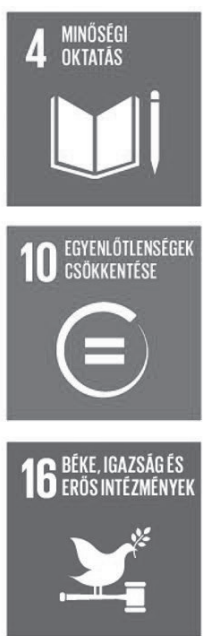
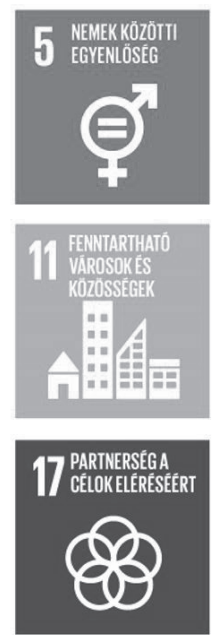
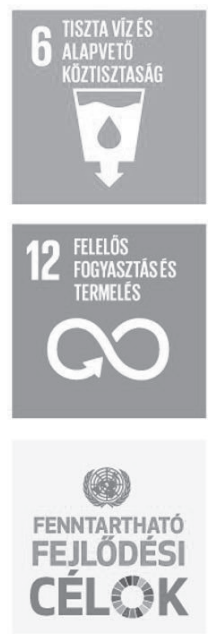

FIG. 1

\section{Az ENSZ 198 tagállama által elfogadott fenntartható fejlódéshez kapcsolódó célok 2030-as Agenda szerint}

(Sustainable Development Goals of the United Nations According to Agenda of 2o3o)

Forrás (Source): Magyar ENSZ Társaság (MENSZT), 2015

Megjegyzés (Notes): (1) No poverty; (2) No hunger; (3) Good health; (4) Quality education; (5) Gender equality; (6) Clean water and sanitation; (7) Clean energy; (8) Goods jobs and economic growth; (9) Innovation and infrastructure; (10) Reduced inequalities; (11) Sustainable cities and communities; (12) Responsible consumption; (13) Protect the planet; (14) Life below water; (15) Life on land; (16) Peace and justice; (17) Partnerships for the goals

\subsection{LOHAS - Lifestyle of Health and Sustainability}

A hazai és nemzetközi fogyasztói magatartás kutatások között a saját kutatási kérdéseinkhez a LOHAS (Lifestyle of Health and Sustainability) csoport tagjairól folyó diskurzusokat tartottuk kiindulópontnak. Ez a nálunk egyre nagyobb számban megjelenő és egyre alaposabban kutatott tudatos fogyasztói csoport a fenntartható fejlődéshez társuló (az etikus, a környezettudatos) és az egészségtudatos értékeket ugyanúgy magáénak érzi. Náluk már az egészségmegőrzésén túl a vásárlásoknál a társadalmi változások előidézése is célként fogalmazódik meg, bár ahogyan ezt korábban említettük, ez nem feltételen jár fogyasztáscsökkentéssel, ami miatt a szakirodalom sok esetben a LOHAS csoport tagjait hedonista fogyasztóként azonosítja (TÖRŐCSIK, 2007; RÁCZ, 2013), ami szembemegy az önkéntes egyszerüség elvével. Ezen csoport vásárlási döntéseinél a fenntartható fejlődés mindhárom - gazdasá- 
gi, társadalmi és ökológiai - pillérét figyelembe veszi (RÁCZ, 2013; KISS, 2015). Megjelennek náluk összevont értékek, mint az életminőség, az autentikusság, a természetesség, így erősen preferálják például a bio- vagy helyi, tájjellegü termékeket, és a slow food mozgalmat (TÖRŐCSIK és DUDÁS, 2007). TÖRÖCSIK 2007-ben még mint trendkövető csoportot azonosította őket, aminek elsősorban egyéni egészség- és környezettudatos életmód célként való megvalósítása adja a karakterét. SCHULZ (2008) kutatásában hibrid életstílusként beszél a LOHAS csoport tagjairól, mivel korábbi vizsgálatok során egymáshoz nem kapcsolódó értékek náluk párban jelennek meg. Ilyen például az énközpontú mégis közösségi, illetve a racionális mégis spirituális gondolkodás, míg cselekvés szintjén az egészség és az élvezet, vagy a modern és autentikus értékek összekapcsolása (SCHULZ, 2008 idézi LEHOTA et al., 2014), illetve hogy elfogadják a tömegszerű termelés ésszerűségét, de a környezetre és az egészségre gyakorolt hatásukat is szem előtt tartják (TÖRÖCSIK, 2007). A LOHAS csoport kritikája más fenntarthatósághoz kapcsolódó mozgalmakhoz képest (KISS, 2015), hogy a túlfogyasztás jelenségére nem jelent megoldást, sőt erre a csoportra inkább egy hedonista életstílus jellemző (TÖRŐCSIK, 2007). A LOHAS-hoz képest a LOVOS-ként (Lifestyle of Voluntary Simplicity) (KREEB et al., 2008) emlegetett irányzat enyhít, mely az önkéntes egyszerüség mozgalmának ideológiájára épít. Az önkéntes egyszerüség alapkitétele a fogyasztás csökkentése (KOCSIS, 2001).

A hazai és nemzetközi kutatásokban is egyértelműen kirajzolódik, hogy hasonló szocio-demográfiai tulajdonságokkal rendelkeznek a csoport tagjai, azaz általában nők, családosak és jó anyagi körülmények jellemzőek rájuk (TÖRÖCSIK, 2007; RÁCZ, 2013; SZAKÁLY et al., 2015). RÁCZ (2013) kutatásában öt faktor mentén különítette el a csoportokat, melyek összecsengnek a fenti jellemzőkkel. Ezek a környezettudatos, az egészségtudatos, az etikus, az autentikus értékek, melyek mellett megjelent az ego vagy egyéniség mint érték, az individualizmus is. Ezen közösségek számára az egészségügy és a fenntarthatóság összeegyeztethető és együttesen fejleszthető, hiszen a környezet minőségének megőrzése természetes úton az egészségmegőrzésében elengedhetetlen (KISS, 2015).

\subsection{Ifjúság - a középiskolások - Young People}

A kutatók és a marketing szakemberek egyaránt szeretik az elmúlt pár évben elterjedt és megszilárdult X, Y, Z, C és Alfa generációs elméleteket. A generációs különbségek nem csak a szociológiai kutatásokban fontosak, de a gazdaságelmélet, fogyasztói magatartás vizsgálatok esetében is bebizonyították létjogosultságukat. Fontos szerepe van a fiatal generáció esetében gondolkodásuk és a viselkedésminta kialakulásában az elsődleges, a másodlagos, és a középiskolások esetében már a harmadlagos szocializációs közegnek is ${ }^{1}$. Főleg a fiatalok körében nagyon intenzív a kortárscsoport hatása a család és az iskola mellett, és ez az idó előrehaladtával növekszik (SZÉKELY, 2013). Felnőtt korukra pedig az átvett értékek mentén alakítják ki saját családjuk elsődleges szocializációs színterét.

A jelen kutatásban szereplő középiskolás csoportra leginkább a $\mathrm{C}$ és $\mathrm{Z}$ generációs elméletek adekvátak. A Z generáció tagjait digitális bennszülötteknek is nevezik, akik már az információs társadalomba születtek 1995 és 2009 között (PRENSKY, 2001)². Jellemző rájuk a multitasking, így figyelmüket vagy érdeklődésüket is jóval nehezebb fenntartani, ők az (inter)net generáció (SZÉKELY, 2013), akik a hagyományos ATL típusú promócióval kevésbé érhetők el (KISS és SZAKÁLY, 2015). Az ifjúsági kultúrához kapcsolódó sztenderdeket teljes egészében a média befolyásolja, és az ifjúsági csoportok közötti különbségek is az információs társadalomhoz való hozzáállásuk mentén jönnek elő (SOMLAI, 2011; SZÉKELY, 2013). Rájuk jellemző, hogy már gyermek éve-

\footnotetext{
${ }^{1}$ Elsődleges szocializációs közeg: család, családi értékek; Másodlagos szocializációs közeg: iskola, munkahely és ezek értékei; Harmadlagos szocializációs közeg: szabadidős terek és tevékenységek, illetve ezeken belül is a média- és kultúrafogyasztás, digitális terek és tevékenységek, sport és formális vagy informális szerveződések (NAGY és TRENCSÉNYI, 2012; SZÉKELY, 2013).

${ }^{2} E z$ a változás konkrét biológiai differenciát is hozott az agymüködésében a digitális bennszülött gyerek esetében mondja egy amerikai orvosprofesszor (BERRY idézi PRENSKY, 2001), így rájuk már teljesen máshogy kell hatni, ha üzeneteket fogalmazunk meg.
} 
ikben aktív fogyasztók lettek (BASSIOUNI és HACKLEY, 2014). A C generációs elméletek (Connected Generation) az „Always On”, azaz a folyamatosan kapcsolódó generációként beszélnek róluk (TÓBI, 2013). Nem egy korosztály tagjai, inkább egy tevékenységi csoporté, akikre jellemző a „Megosztok, tehát vagyok” (NIELSEN, 2010) mentalitás. Jellemző rájuk többek között a törzsi viselkedés, a társadalmi státusz megosztásokkal való reprezentálása, „méhkasszerü” viselkedés - a Mi előretörése az Énnel szemben és a társas alkotás, teremtés preferálása (NIELSEN, 2010; KIETZMANN, 2014).

A fiatalokat bemutató országos reprezentatív és korosztályukra fókuszáló kutatásokból az derült ki, hogy 91\% elégedett az egészségével (KSH, 2015), illetve a HBSC kutatások is 2006-ról 2010-re jóval kedvezőbb állapotokról számolnak be az egészségi állapot, valamint a szociális és egyéni lelki állapot felmérések alapján (ZSIROS et al., 2012). Továbbá anyagi helyzetüket is jobbnak ítélik, mint az idősebb generáció tagjai (KISS és SZAKÁLY, 2015).

Fiatalok tudatosságát vizsgáló kutatást mind nemzetközi, mind hazai szinten csekély számban találunk. A fóbb kérdések ebben a témakörben fogyasztói magatartásukat illetően környezet- vagy egészségtudatosságra irányulnak (BENN, 2004; BOYES et al., 2008; MICHALOS et al., 2009; MARJAINÉ et al., 2010, 2012a, 2012b; FRANTZ és CHANDEU, 2011; ZSÓKA, MARJAINÉ és SZÉCHY, 2011; FINTOR, 2015). A kutatók arról számolnak be, hogy a fiatalok gondolkodás módjában a tudatossághoz kapcsolt értékek jelennek meg, de ezek figyelembe vétele a nevelési keretek, a kor és az előzetes tudásuk alapján differenciálódik a különböző csoportok között. Például komoly különbséget találtak a fejlett és fejlődő országok fiataljainak etnocentrikus gondolkodásában is (JIN et al., 2015).

A különböző, ezt a korosztályt célzó hazai és nemzetközi kutatások is igazolták, hogy sok esetben a nyugat-európai mintáktól eltérően a társadalmihelyzet-mutatók, az otthoni környezet erős hatást gyakorol a magyar fiatalok magatartására mind a szabadidő-struktúra, a fizikai aktivitás, az általános viselkedésük, mind a napi étkezéseik minőségének kapcsán (PIKÓ, 2005; SPURRIER et al., 2008). Ezen korosztály esetében - mivel pontosan tudjuk, hol találjuk őket - a különböző preventív tevékenységek célravezetőek lehetnek. Az elsődleges prevenció célja: ismeretek átadása, életmódbeli káros hatások bemutatása, továbbá bizonyos szociálpszichológiai és kognitív ismeretekre építő attitűdformálás, készségfejlesztés (PIKÓ, 2003; KRISTON és PIKÓ, 2016). Ehhez azonban a csoport alapos megismerésére és a csoporton belüli differenciák feltárására van szükség, melyet jelen tanulmány is célul tűzött ki.

\section{ANYAg ÉS MÓDSZER - \\ MATERIAL AND METHOD}

\subsection{A kutatás és a minta bemutatása - Introduction of the Research and Material}

Az egészségtudatosság és a fenntarthatóság értékei iránt elköteleződő ifjúsági csoport feltárására egy 1320 fős kérdőíves megkérdezést bonyolítottuk le a 2015/2016-os tanévben 13 intézmény diákjainak bevonásával, akik közül végül 1002 fő került a mintába. A KSH 2015. évi adatai alapján a minta nemre ebben a korosztályban reprezentatív. A mintában enyhén felülreprezentáltak a gimnazisták (1 és $1_{b}$ táblázat).

Az eredmények értékelését az IBM SPSS 22.0 verziójával készítettük el, melynek segítségével a minta megoszlási mutatóit (átlag, módusz, csoportos medián, ferdeség és interkvartilis terjedelem) elemeztük, továbbá faktoranalízissel és klaszterelemzéssel alakítottunk ki csoportokat, melyeket a háttérváltozók mentén kereszttáblás elemzésekkel vizsgáltunk tovább. A teljes kutatásból jelen tanulmányban felhasznált rész az elméleti áttekintésben szereplő témakörökre épült (tudatos fogyasztás, egészségtudatosság, fenntartható fejlődés). 
A minta megoszlása a háttérváltozók mentén

TABLE 1

\section{(The Socio-demographic Background of the Sample)}

\begin{tabular}{|c|c|c|c|}
\hline & \multirow[t]{2}{*}{$\begin{array}{l}\text { Megnevezés } \\
\text { (Criterion) }\end{array}$} & \multicolumn{2}{|c|}{$\begin{array}{l}\text { A minta } \\
\text { megoszlása } \\
\text { (Division of } \\
\text { the Sample) }\end{array}$} \\
\hline & & $\mathbf{N}$ & $\%$ \\
\hline \multicolumn{2}{|l|}{ Összesen (Total) } & 1002 & 100,0 \\
\hline \multirow{3}{*}{$\begin{array}{l}\text { Neme } \\
\text { (Gender) }\end{array}$} & Nő (Women) & 475 & 47,4 \\
\hline & Férfi (Men) & 500 & 49,9 \\
\hline & Nem válaszolt (No answer) & 27 & 2,7 \\
\hline \multirow{4}{*}{$\begin{array}{l}\text { Iskolatípusa } \\
\text { (School type) }\end{array}$} & Gimnázium (High school) & 554 & 55,3 \\
\hline & Szakközépiskola (Secondary school) & 341 & 34,0 \\
\hline & Szakiskola (Vocational School) & 102 & 10,2 \\
\hline & Nem válaszolt (No answer) & 5 & 0,5 \\
\hline \multirow{4}{*}{$\begin{array}{l}\text { Kor } \\
\text { (Age) }\end{array}$} & $14-15$ & 209 & 20,9 \\
\hline & 16 & 203 & 20,3 \\
\hline & 17 & 273 & 27,2 \\
\hline & $18-19$ & 317 & 31,6 \\
\hline \multirow{6}{*}{$\begin{array}{l}\text { Anya iskolai } \\
\text { végzettsége } \\
\text { (Mother's Education) }\end{array}$} & Általános iskola (Primary School) & 119 & 11,9 \\
\hline & Szakközép- és szakiskola (Secondary and Vocational School) & 208 & 20,8 \\
\hline & Érettségi (High School Graduate) & 297 & 29,6 \\
\hline & Felsőfokú (Higher Eduacation Graduate) & 294 & 29,3 \\
\hline & Nem tudja (Not know) & 37 & 3,7 \\
\hline & Nem válaszolt (No answer) & 47 & 4,7 \\
\hline \multirow{6}{*}{$\begin{array}{l}\text { Apa iskolai } \\
\text { végzettsége } \\
\text { (Father's Education) }\end{array}$} & Általános iskola (Primary School) & 94 & 9,4 \\
\hline & Szakközép- és szakiskola (Secondary and Vocational School) & 352 & 35,2 \\
\hline & Érettségi (High School Graduate) & 205 & 20,5 \\
\hline & Felsőfokú (Higher Eduacation Graduate) & 237 & 23,7 \\
\hline & Nem tudja (Not know) & 59 & 5,9 \\
\hline & Nem válaszolt (No answer) & 55 & 5,5 \\
\hline \multirow{5}{*}{$\begin{array}{l}\text { Családi szubjektív anyagi } \\
\text { helyzete* } \\
\text { (Family's Subjective } \\
\text { Income) }\end{array}$} & $\begin{array}{l}\text { Nagyon jól megélünk belőle, és még félre is tudunk tenni (Can live on it } \\
\text { very well and can also save) }\end{array}$ & 322 & 32,1 \\
\hline & $\begin{array}{l}\text { Megélünk belőle, de keveset tudunk félretenni (Can live on it, but can } \\
\text { save a little) }\end{array}$ & 387 & 38,7 \\
\hline & $\begin{array}{l}\text { Elegendő, de félretenni már nem tudunk (Just enough to live on, but } \\
\text { cannot save) }\end{array}$ & 155 & 15,5 \\
\hline & $\begin{array}{l}\text { Néha arra sem elég, hogy megéljünk belőle/Állandó anyagi problémákkal } \\
\text { küzdünk (Sometimes cannot make ends meet/Have regular financial } \\
\text { problems) }\end{array}$ & 41 & 4,1 \\
\hline & Nem válaszolt (No answer) & 97 & 9,7 \\
\hline
\end{tabular}

Forrás (Source): Saját kutatás, 2016 (Own construction, 2016)

Megjegyzés (Notes): *A család szubjektív jövedelmének megítélésénél - az alacsony arány miatt - az alsó két kategória összevonásra került. (We contracted the bottom two categories about the family's subjective income because of the low rate.) 


\begin{tabular}{|c|c|c|c|}
\hline & \multirow[t]{2}{*}{$\begin{array}{l}\text { Megnevezés } \\
\text { (Criterion) }\end{array}$} & \multicolumn{2}{|c|}{$\begin{array}{l}\text { A minta } \\
\text { megoszlása } \\
\text { (Division of } \\
\text { the Sample) }\end{array}$} \\
\hline & & $\mathbf{N}$ & $\%$ \\
\hline \multicolumn{2}{|l|}{ Összesen (Total) } & 1002 & 100,0 \\
\hline \multirow{3}{*}{$\begin{array}{l}\text { Településtípusa } \\
\text { (Settlement) }\end{array}$} & Megyei jogú város (County town) & 438 & 43,7 \\
\hline & 2 ooo fónél nagyobb település (Town with more than 2 ooo residents) & 437 & 43,6 \\
\hline & 2 ooo fónél kisebb település (Settlement with less than 2 ooo residents) & 119 & 11,9 \\
\hline \multirow{7}{*}{$\begin{array}{l}\text { Testtömeg index - } \\
\text { BMI** } \\
\text { (Body Mass Index) }\end{array}$} & Súlyhiány, kóros soványság (Emaciation) & 75 & 7,5 \\
\hline & Sovány (Thinness) & 64 & 6,4 \\
\hline & Megfelelő (Normal) & 517 & 51,6 \\
\hline & Súlyfölösleg, túltápláltság (Overfed) & 187 & 18,7 \\
\hline & Túlsúlyos (Overweight) & 64 & 6,4 \\
\hline & Kóros elhízás (Obesity) & 49 & 4,9 \\
\hline & Nem válaszolt (No answer) & 45 & 4,5 \\
\hline
\end{tabular}

Forrás (Source): Saját kutatás, 2016 (Own construction, 2016)

Megjegyzés (Notes): **A BMI számítás az OGYEI gyermekekre kialakított táblázata alapján készült (PINTÉR, 2004).

( ${ }^{* *}$ The calculation of BMI is about the OGYEI's table (PINTÉR, 2004))

\section{Eredmények - Results}

\subsection{LOHAS állítások megítélése a középiskolások körében - Values of LOHAS According to Young Consumers}

TÖRŐCSIK (2003) elmélete szerint, már létezik egy úgynevezett kis LOHAS csoport, akik a felnőttekhez hasonlóan tudatosan élik mindennapjaikat egészség és fenntarthatóság (elsősorban környezettudatosság) szempontjából, és jellemző náluk az énközpontúság. Ennek feltérképezésére egy korábban már validált (RÁCZ, 2013; SZAKÁLY et al., 2015) kérdéssort használtunk. A 25 állításról a középiskolás diákokat is megkérdeztük Likert-skálás kérdésekben, melyeknél az 1, az egyáltalán nem ért egyet, míg az 5, a teljes mértékben egyetért válaszok voltak. A kiértékelést a $2_{a}$ és $2_{b}$ táblázat mutatja. A $2_{a}$ és $2_{b}$ táblázatban szereplő állításokat csoportos medián és ferdeség szerint állítottuk csökkenő sorrendbe. Az első három helyen lévő állításnál a csoportos medián értéke 4,4 feletti, ezekkel értettek egyet legjobban a diákok, és ezeknek a ferdesége is megfelelő értéket képvisel. Ezek az állítások a késóbbi karrier sikerességére, a sport fontosságára és a környezettudatos oktatás szükségességére irányultak, melyekkel a diákság legnagyobb arányban értett egyet. A nagyfokú egyetértésből fakadhat, hogy a faktoranalízis során ez a három állítás nem illeszkedett egyik faktorhoz sem megfelelően. A mintában szereplő alanyokat leginkább megosztó állítások az etikus értékekhez köthetők. Ez a korábban elvégzett országos reprezentatív kutatás (SZAKÁLY et al., 2015) eredményeivel összecseng, és összességében is elmondhatjuk, hogy a középiskolások attitüdjei nagyon hasonlóak a teljes felnőtt lakosságéhoz. 
2 TÁBLÁzAT

TABLE 2

Az egészségtudatossághoz és a fenntartható fejlődéshez kapcsolódó állítások megítélése

a középiskolás diákok körében

(Agreement with Health-conscious and Sustainable Value-based Lifestyle According to the 14-19 Aged Young Consumers)

\begin{tabular}{|c|c|c|c|c|c|c|}
\hline \multirow{3}{*}{$\begin{array}{c}\text { Állítások } \\
\text { (Statements) }\end{array}$} & \multicolumn{6}{|c|}{$\begin{array}{c}\text { Statisztikai mutatók } \\
\text { (Statistical Indicators) }\end{array}$} \\
\hline & \multirow[t]{2}{*}{ 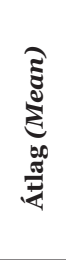 } & \multirow[t]{2}{*}{ 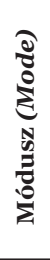 } & \multirow[t]{2}{*}{ 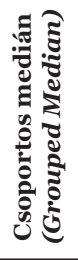 } & \multirow[t]{2}{*}{ 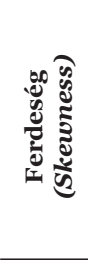 } & \multicolumn{2}{|c|}{ 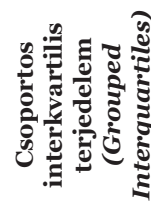 } \\
\hline & & & & & Q1 & Q3 \\
\hline $\begin{array}{l}\text { Fontos számomra a siker, a későbbi karrierem. (Carrier is important to } \\
\text { me.) }\end{array}$ & 4,41 & 5 & $4,54^{\mathrm{a}}$ & $-1,550$ & 4,54 & - \\
\hline $\begin{array}{l}\text { Az egészség megőrzéséhez nélkülözhetetlen a sport. (Sport is essential to } \\
\text { stay healthy.) }\end{array}$ & 4,28 & 5 & $4,45^{\mathrm{a}}$ & $-1,289$ & 3,62 & - \\
\hline $\begin{array}{l}\text { Szükséges, hogy a gyerekek környezettudatos nevelésben részesüljenek. } \\
\text { (Children should be educated environmental-consciously.) }\end{array}$ & 4,30 & 5 & $4,41^{\mathrm{a}}$ & $-1,193$ & 3,65 & - \\
\hline $\begin{array}{l}\text { Rendszerint szezonális termékeket (pl. dinnye augusztusban) vásárolok. } \\
\text { (I usually buy seasonal products, e.g. watermelon in August.) }\end{array}$ & 4,10 & 5 & $4,27^{\mathrm{a}}$ & $-1,057$ & 3,38 & 4,93 \\
\hline $\begin{array}{l}\text { Előnyben részesítem az olyan élelmiszereket, amelyek hozzájárulnak } \\
\text { egészségem megőrzéséhez. (I prefer foods that contribute to staying } \\
\text { healthy.) }\end{array}$ & 4,10 & 5 & $4,22^{\mathrm{a}}$ &,- 875 & 3,37 & 4,89 \\
\hline $\begin{array}{l}\text { Az egészséges táplálkozás szempontjából fontos, hogy az ember tisztában } \\
\text { legyen az élelmiszerösszetevők (pl. vitaminok, ásványi anyagok, élelmi } \\
\text { rostok) élettani hatásaival. (From the view of healthy nutrition it is } \\
\text { important to be aware of the physiological effects of food ingredients, } \\
\text { e.g. vitamins, minerals, fibers.) }\end{array}$ & 4,02 & 5 & $4,16^{\mathrm{a}}$ &,- 919 & 3,30 & 4,84 \\
\hline $\begin{array}{l}\text { Kedvezóbben ítélem meg azt a vállalatot, amelyik megfelelő } \\
\text { munkakörülményeket biztosít alkalmazottai számára. (I consider the } \\
\text { company that provides good working conditions for its employees } \\
\text { better.) }\end{array}$ & 3,98 & 5 & $4,14^{a}$ &,- 900 & 3,24 & 4,84 \\
\hline $\begin{array}{l}\text { Az energiatakarékos háztartási berendezések hozzájárulnak a fenn- } \\
\text { tartható fejlődéshez. (Energy saving household gadgets contribute to } \\
\text { sustainable development.) }\end{array}$ & 3,95 & 4 & $4,05^{\mathrm{a}}$ &,- 698 & 3,21 & 4,77 \\
\hline $\begin{array}{l}\text { Ha a helyi piacokon vásárolok élelmiszert, akkor azzal a magyar } \\
\text { termelőket támogatom. (If I purchase food on the local markets, } \\
\text { then I support Hungarian producers.) }\end{array}$ & 3,84 & 5 & $4,01^{a}$ &,- 799 & 3,06 & 4,78 \\
\hline Fontos számomra a stílus. (Style is important to me.) & 3,86 & 5 & $3,99^{\mathrm{a}}$ &,- 684 & 3,09 & 4,75 \\
\hline
\end{tabular}

aA csoportos adatokból számított medián (Median calculated by the group data)

Megjegyzés (Notes): A hiányzó adatok mennyisége egyik állítás esetében sem éri el a 4\%-ot. (The amount of missing data does not reach 4 percent in the case of any statements.) 
Az egészségtudatossághoz és a fenntartható fejlődéshez kapcsolódó állítások megítélése a középiskolás diákok körében

(Agreement with Health-conscious and Sustainable Value-based Lifestyle According to the 14-19 Aged Young Consumers)

\begin{tabular}{|c|c|c|c|c|c|c|}
\hline \multirow{3}{*}{$\begin{array}{c}\text { Állítások } \\
\text { (Statements) }\end{array}$} & \multicolumn{6}{|c|}{$\begin{array}{c}\text { Statisztikai mutatók } \\
\text { (Statistical Indicators) }\end{array}$} \\
\hline & \multirow[t]{2}{*}{ 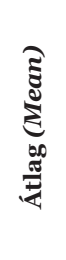 } & \multirow[t]{2}{*}{ 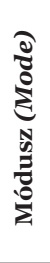 } & \multirow[t]{2}{*}{ 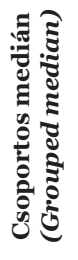 } & \multirow[t]{2}{*}{ 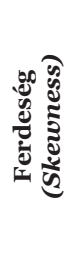 } & \multicolumn{2}{|c|}{ 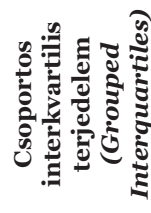 } \\
\hline & & & & & Q1 & Q3 \\
\hline $\begin{array}{l}\text { Az élelmiszerekben megtalálható adalékanyagok károsítják az } \\
\text { egészségemet. (Additives in foods are hazardous to my health.) }\end{array}$ & 3,82 & 5 & $3,93^{\mathrm{a}}$ &,- 623 & 3,02 & 4,75 \\
\hline $\begin{array}{l}\text { Magyar termékek vásárlásával hozzájárulok az ország gazdasági } \\
\text { fejlődéséhez. (I contribute to the economic development of the country by } \\
\text { buying Hungarian products.) }\end{array}$ & 3,72 & 4 & $3,82^{\mathrm{a}}$ &,- 628 & 2,93 & 4,66 \\
\hline $\begin{array}{l}\text { A magas minőségű termékeket kedvelem. (I prefer high quality } \\
\text { products.) }\end{array}$ & 3,74 & 4 & $3,82^{\mathrm{a}}$ &,- 598 & 2,99 & 4,65 \\
\hline A márkás termékeket részesítem előnyben. (I prefer branded products.) & 3,69 & 4 & $3,77^{\mathrm{a}}$ &,- 615 & 2,92 & 4,60 \\
\hline $\begin{array}{l}\text { Olyan termékeket vásárolok, amelyek tükrözik személyiségemet. (I buy } \\
\text { products that reflect my personality.) }\end{array}$ & 3,58 & 4 & $3,68^{\mathrm{a}}$ &,- 543 & 2,69 & 4,58 \\
\hline $\begin{array}{l}\text { Fontos számomra a hagyományok tisztelete. (Respect of traditions is } \\
\text { important to me.) }\end{array}$ & 3,57 & 4 & $3,65^{\mathrm{a}}$ &,- 470 & 2,69 & 4,54 \\
\hline $\begin{array}{l}\text { A termékeken szereplő védjegyek (pl. magyar termék) csökkentik a } \\
\text { bizonytalanságot a vásárlás során. (Trademarks on the products (e.g. } \\
\text { Hungarian product) reduce uncertainty during shopping.) }\end{array}$ & 3,45 & 3 & $3,52^{\mathrm{a}}$ &,- 437 & 2,58 & 4,41 \\
\hline $\begin{array}{l}\text { Napi étkezésem tervezésekor figyelek arra, megfelelő mennyiségben } \\
\text { hozzájussak a szervezetem számára nélkülözhetetlen tápanyagokhoz. } \\
\text { (When I plan my daily meals I am careful that my body should get all } \\
\text { the necessary nutrients.) }\end{array}$ & 3,42 & 3 & $3,49^{\mathrm{a}}$ &,- 376 & 2,52 & 4,40 \\
\hline $\begin{array}{l}\text { Kedvezóbben ítélem meg azt a vállalatot, amelyik jótékonysági akciókat } \\
\text { támogat. (I consider the company that donates to charities better.) }\end{array}$ & 3,33 & 3 & $3,42^{\mathrm{a}}$ &,- 357 & 2,41 & 4,33 \\
\hline $\begin{array}{l}\text { Az egyedi kivitelezésű termékeket kedvelem. (I prefer uniquely designed } \\
\text { products.) }\end{array}$ & 3,38 & 3 & $3,39^{\mathrm{a}}$ &,- 201 & 2,55 & 4,21 \\
\hline $\begin{array}{l}\text { Fontos, hogy a megvásárolt termék csomagolása újrahasznosítható } \\
\text { legyen. (It is important that the packing of the product should be } \\
\text { recyclable.) }\end{array}$ & 3,06 & 3 & $3,12^{\mathrm{a}}$ &,- 160 & 2,19 & 3,94 \\
\hline $\begin{array}{l}\text { Kizárólag állatkísérletektől mentes termékeket vásárolok. (I only buy } \\
\text { products free of animal experiments.) }\end{array}$ & 3,04 & 3 & $3,09^{\mathrm{a}}$ &,- 084 & 2,02 & 4,10 \\
\hline $\begin{array}{l}\text { A legújabb divat szerint alakítom életvitelemet. (I live considering the } \\
\text { latest fashion.) }\end{array}$ & 2,99 & 3 & $3,06^{\mathrm{a}}$ &,- 113 & 2,06 & 3,94 \\
\hline Évente végzek önkéntes munkát. (I do charity work annually.) & 2,48 & 1 & $2,30^{\mathrm{a}}$ & 462 & 1,32 & 3,57 \\
\hline $\begin{array}{l}\text { Rendszerint adományokkal támogatom a civil szervezetek munkáját. } \\
\text { (I regularly support the work of charity organizations with donations.) }\end{array}$ & 2,27 & 1 & $2,14^{\mathrm{a}}$ &, 548 & 1,28 & 3,16 \\
\hline
\end{tabular}

aA csoportos adatokból számított medián (Median calculated by the group data)

Megjegyzés (Notes): A hiányzó adatok mennyisége egyik állítás esetében sem éri el a 4\%-ot. (The amount of missing data does not reach 4 percent in the case of any statements.) 


\subsection{A faktoranalízis eredményei - Results of the Factor Analysis}

Az állítások önálló vizsgálata után főkomponens elemzéssel olyan értékeket azonosítottunk be, melyek kitöltőink egyes válaszait transzformálva kisebb számú változóban a lehető legnagyobb információtömeget őrzik meg azokból (SZÉKELYI és BARNA, 2008). A faktorsúlyok beállítása és a rotálások után 20 állítás vált alkalmassá az elemzésre, illetve 906 fő vált alkalmassá a vizsgálatra. Ezt az indokolja, hogy néhány esetben kihagyták egy-egy kérdés kitöltését, de ez egy állítás esetében sem volt több mint 4\%, és az ehhez közelítő hiány is csak az utolsó három helyen szereplő állításoknál volt. A diákok válaszai alapján öt faktort tudtunk kialakítani. A faktorsúly minden esetben o,53 feletti. Ezeket a $3_{a}$ és $3_{b}$ táblázat szemlélteti. A kialakított faktorok megbízhatóságának bizonyítására minden esetben megvizsgáltuk a Cronbach' Alpha értéket is, mely minden faktor önálló vizsgálatánál o,50 feletti, illetve a teljes állítássor esetében o,812 lett. A faktorok saját értéke minden esetben nagyobb volt mint 1 . A totál variancia 54,5\%, így elmondhatjuk, a főkomponens megőrzi az eredeti információtartalmának több mint felét. A változószett alkalmasságát látens struktúrakeresésre a KMO érték vizsgálatával végeztük, mely o,83, és ez a szignifikancia vizsgálattal együtt a faktorok alkalmasságáról tanúskodik a további elemzésre (SZÉKELYI és BARNA, 2008).

A főkomponens-elemzés segítségével öt faktort különítettünk el:

Ahogyan az országos felnőtt mintában is, az első faktorba az Individuális értékek (hat állítás) kerültek, melyek leginkább a divat és a minőségi termékek vásárlásához kapcsolódnak, így Trendkövető Individuális faktornak neveztük el (magyarázó variancia=23,02\%). Ebben a csoportban az önmegvalósítás, a saját érdekekhez kapcsolódó állítások jelennek meg, melyek a stílus, a márka, a személyiség és a minőségi jellemzőkre épülnek. A magas faktorsúlyok azt mutatják, hogy ez az értékdimenzió a középiskolásokat is a felnőttekhez hasonlóan erősen befolyásolja, de a faktorsúlyok közötti különbségek a többi faktorhoz képest nem olyan számottevőek, mint a teljes lakosság felmérésében (SZAKÁLY et al., 2015).

A második faktorba tömörült az Egészségés a Környezettudatossághoz kapcsolódó öt állítás (magyarázó variancia=12,38\%). Idetartoznak a környezetvédelemhez (újrahasznosítás) és a fenntarthatósághoz (energiatakarékosság) kapcsolódó, illetve az egészség megőrzéséhez és a tudatossághoz (összetételre, minőségre való odafigyelés) tartozó értékek. SZAKÁLY és munkatársainak (2015) kutatás eredményeivel összevetve itt nem különülnek el egymástól az egészség- és környezettudatossághoz kapcsolódó értékek, míg RÁCZ (2013) kutatásában hasonlóan egy értékcsoportba tömörülnek.

A harmadik faktorban találhatóak az Autentikus Patrióta értékek, melybe négy állítás került (magyarázó variancia: 7,371\%). Ezek a hazai és a helyi termékek, továbbá a hozzájuk kapcsolódó értékek támogatására és a hagyományok tiszteletére irányulnak. A faktorsúlyok alapján megállapíthatjuk, hogy a legerősebb érték a magyar termékek támogatása a teljes lakossághoz hasonlóan (SZAKÁLY et al., 2015).

A negyedik faktor az Altruista és az Etikus értékeket foglalja magában, melyek az önkéntességhez és az adományozáshoz kötődnek (magyarázó variancia: 6,341\%). Ezeket az állításokat érezték a legkevésbé jellemzőnek magukra a diákok az állítások külön-külön vizsgálatánál (lásd $2_{a}$ és $2_{b}$ táblázat).

Az ötödik faktorba kerültek a Vállalatok etikus magatartásával kapcsolatos állítások (magyarázó variancia: 5,394\%). Ezek is etikus kötődésűek, de már nem saját magukkal szembeni cselekvési motivációt takarnak, hanem a vállalati szereplőkkel kapcsolatos elvárásokat. Idetartozik a jótékonysági, a társadalmi felelősségvállalás kérdése, illetve a vállalatok megfelelő munkahelyként való megítélése. 
A fökomponenselemzés során kapott faktorok és faktorsúlyok bemutatása
(Factors Formed Based on Health-conscious and Sustainable Lifestyle)

\begin{tabular}{|c|c|c|c|c|c|}
\hline \multirow[b]{2}{*}{ Állítások (Statements) } & \multicolumn{5}{|c|}{ Faktorok (Factors) } \\
\hline & 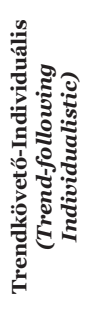 & 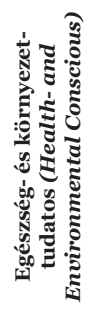 & 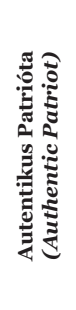 & 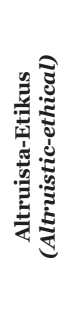 & 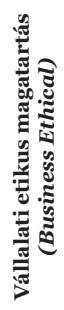 \\
\hline Fontos számomra a stílus. (Style is important to me.) & 0,752 & & & & \\
\hline $\begin{array}{l}\text { A legújabb divat szerint alakítom életvitelemet. (I live considering the } \\
\text { following fashion.) }\end{array}$ & 0,717 & & & & \\
\hline A márkás termékeket részesítem előnyben. (I prefer branded products.) & 0,706 & & & & \\
\hline A magas minőségű termékeket kedvelem. (I prefer high quality products.) & 0,694 & & & & \\
\hline $\begin{array}{l}\text { Olyan termékeket vásárolok, amelyek tükrözik személyiségemet. } \\
\text { (I buy products that reflect my personality.) }\end{array}$ & 0,608 & & & & \\
\hline $\begin{array}{l}\text { Az egyedi kivitelezésű termékeket kedvelem. (I prefer uniquely designed } \\
\text { products.) }\end{array}$ & 0,603 & & & & \\
\hline $\begin{array}{l}\text { Előnyben részesítem az olyan élelmiszereket, amelyek hozzájárulnak } \\
\text { egészségem megőrzéséhez. (I prefer foods that contribute to staying healthy.) }\end{array}$ & & 0,729 & & & \\
\hline $\begin{array}{l}\text { Napi étkezésem tervezésekor figyelek arra, megfelelő mennyiségben } \\
\text { hozzájussak a szervezetem számára nélkülözhetetlen tápanyagokhoz. (When I } \\
\text { plan my daily meals I am careful that my body should get all the necessary } \\
\text { nutrients.) }\end{array}$ & & 0,710 & & & \\
\hline $\begin{array}{l}\text { Az egészséges táplálkozás szempontjából fontos, hogy az ember tisztában } \\
\text { legyen az élelmiszerösszetevók (pl. vitaminok, ásványi anyagok, élelmi } \\
\text { rostok) élettani hatásaival. (From the view of healthy nutrition, it is } \\
\text { important to be aware of the physiological effects of food ingredients, e.g. } \\
\text { vitamins, minerals, fibers.) }\end{array}$ & & 0,628 & & & \\
\hline $\begin{array}{l}\text { Fontos, hogy a megvásárolt termék csomagolása újrahasznosítható legyen. } \\
\text { (It is important that the packing of the product should be recyclable.) }\end{array}$ & & 0,608 & & & \\
\hline $\begin{array}{l}\text { Az energiatakarékos háztartási berendezések hozzájárulnak a fenntartható } \\
\text { fejlődéshez. (Energy saving household gadgets contribute to sustainable } \\
\text { development.) }\end{array}$ & & 0,601 & & & \\
\hline $\begin{array}{l}\text { Magyar termékek vásárlásával hozzájárulok az ország gazdasági fejlődéséhez. } \\
\text { (I contribute to the economic development of the country by buying } \\
\text { Hungarian products.) }\end{array}$ & & & 0,790 & & \\
\hline $\begin{array}{l}\text { Ha a helyi piacokon vásárolok élelmiszert, akkor azzal a magyar termelőket } \\
\text { támogatom. (If I purchase food on the local markets, then I support } \\
\text { Hungarian producers.) }\end{array}$ & & & 0,699 & & \\
\hline $\begin{array}{l}\text { A termékeken szereplő védjegyek (pl. magyar termék) csökkentik a } \\
\text { bizonytalanságot a vásárlás során. (Trademarks on the products } \\
\text { (e.g. Hungarian product) reduce uncertainty during shopping.) }\end{array}$ & & & 0,696 & & \\
\hline $\begin{array}{l}\text { Fontos számomra a hagyományok tisztelete. (Respect of traditions is } \\
\text { important to me.) }\end{array}$ & & & 0,615 & & \\
\hline
\end{tabular}




\section{$3_{b}$ TÁBLÁZAT}

A főkomponenselemzés során kapott faktorok és faktorsúlyok bemutatása (Factors Formed Based on Health-conscious and Sustainable Lifestyle)

TABLE $3_{b}$

Faktorok (Factors)

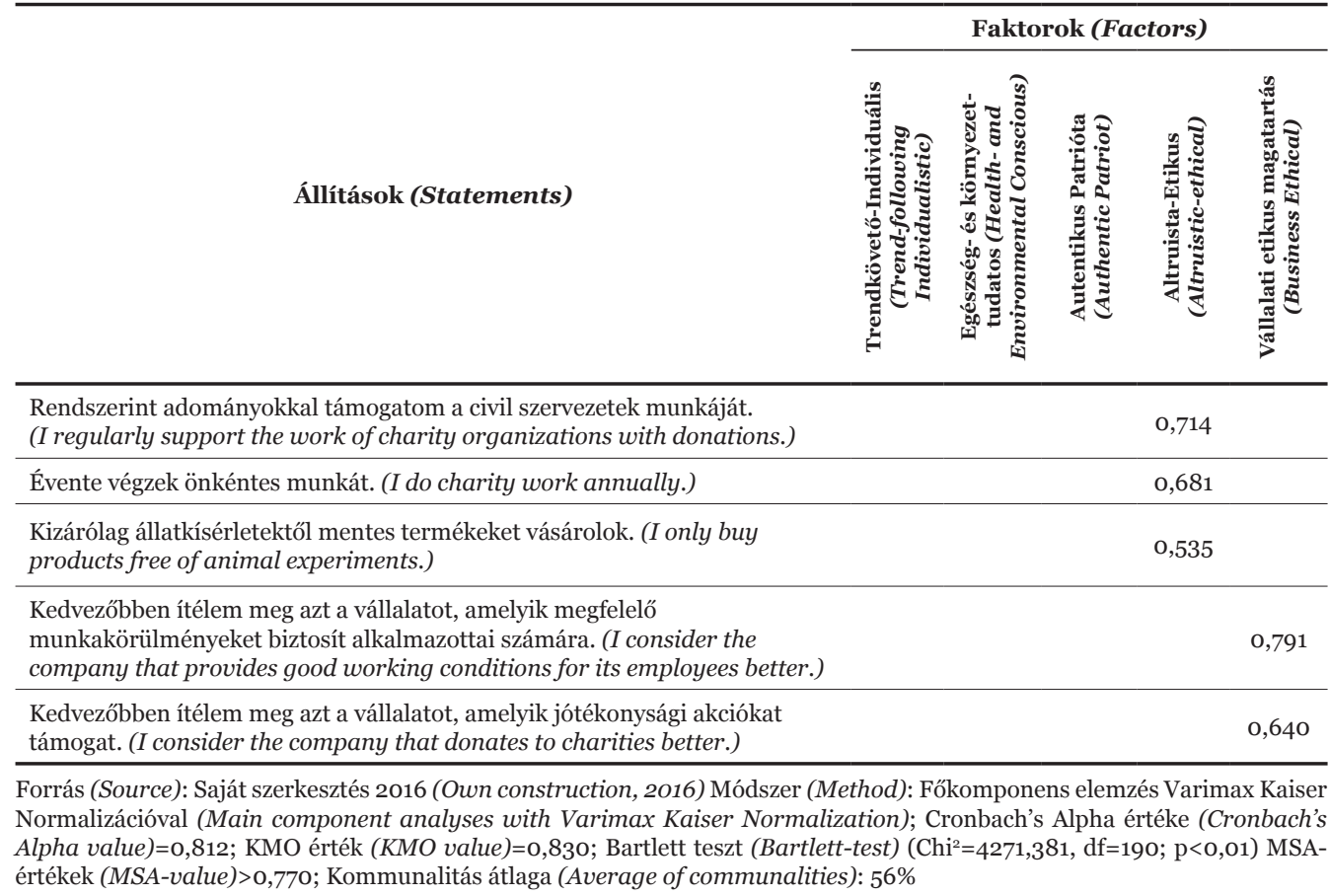

A következő lépésben a faktorokat az egyes szocio-demográfiai háttérváltozók mentén is megvizsgáltuk varianciaanalízis (ANOVA) segítségével (4. táblázat). Az individuális, a divathoz kapcsolódó értékek jellemzóbbek az alsóbb évesekre, a szakközépiskolásokra, a kisebb településen élőkre. A családi jövedelemmel való összevetéskor a legjobb és a legrosszabb körülmények között élőkre jellemző leginkább a trendkövetés. Ezt magyarázhatja, hogy amíg a legjobb jövedelmi helyzetben élő diákok megengedhetik maguknak a trendkövetést, addig a rosszabb körülmények között élőknek a divat státuszszimbólumként vagy vágyként fogalma- zódik meg. Az egészség- és környezettudatos értékek inkább a fiúkra jellemzőek, továbbá ezen értékek preferálói jellemzően felsôbb évesek, megyei jogú város lakosai és magasan iskolázott apák gyermekei. Az autentikus értékek is jobban jellemzik a fiúkat és a jobb jövedelmi helyzetű családok gyermekeit. Az altruistaetikus értékcsoport más szociológiai kutatásokkal (FÉNYES, 2016) összecsengve a lányokra jellemzőbb. A vállalatok etikus magatartását pedig inkább a felsőbb éves, magasabb jövedelmű családból jövő fiatalok tartják szem előtt. A BMI indexszel egyik értékcsoport esetében sem találtunk összefüggést. 
A faktorok bemutatása szocio-demográfiai változók tükrében (Value Factors According to Socio-demographic Background Variables)

\begin{tabular}{|c|c|c|c|c|c|}
\hline \multirow[b]{2}{*}{$\begin{array}{c}\text { Szocio- } \\
\text { demográfiai } \\
\text { változók } \\
\text { (Socio- } \\
\text { demographic } \\
\text { Variables) }\end{array}$} & \multicolumn{5}{|c|}{ Faktorok és elnevezésük (Factors and Their Nominations) } \\
\hline & $\begin{array}{l}\text { Trendkövetó- } \\
\text { Individuális } \\
\text { (Trend-following } \\
\text { Individualistic) }\end{array}$ & $\begin{array}{c}\text { Egészség és } \\
\text { környezet-tudatos } \\
\text { (Health-and } \\
\text { Environmental } \\
\text { Conscious) }\end{array}$ & $\begin{array}{l}\text { Autentikus } \\
\text { Patrióta } \\
\text { (Authentic } \\
\text { Patriot) }\end{array}$ & $\begin{array}{l}\text { Altruista- } \\
\text { Etikus } \\
\text { (Altruistic- } \\
\text { ethical) }\end{array}$ & $\begin{array}{c}\text { Vállalati } \\
\text { etikus } \\
\text { magatartás } \\
\text { (Business } \\
\text { Ethical) }\end{array}$ \\
\hline Nem (Gender) & $\begin{array}{l}\text { nincs hatás } \\
\text { (not found) }\end{array}$ & $\begin{array}{l}\text { ** férfiakra } \\
\text { jellemzóbb } \\
\text { (rather men) }\end{array}$ & $\begin{array}{l}\text { ** férfiakra } \\
\text { jellemzóbb } \\
\text { (rather men) }\end{array}$ & $\begin{array}{l}\text { **inkább nók } \\
\text { (rather women) }\end{array}$ & $\begin{array}{l}\text { ***inkább } \\
\text { férfiak } \\
\text { (rather men) }\end{array}$ \\
\hline Kor (Age) & $\begin{array}{l}\text { nincs hatás } \\
\text { (not found) }\end{array}$ & $\begin{array}{l}\text { **inkább a } 17 \\
\text { felettiek (rather } \\
\text { older than 17) }\end{array}$ & $\begin{array}{l}\text { nincs hatás } \\
\text { (not found) }\end{array}$ & $\begin{array}{l}\text { **inkább 17-18 } \\
\text { évesek (rather } \\
17-18 \text { olds) }\end{array}$ & $\begin{array}{l}\text { nincs hatás } \\
\text { (not found) }\end{array}$ \\
\hline $\begin{array}{l}\text { Évfolyam (School } \\
\text { year) }\end{array}$ & $\begin{array}{l}\text { ** inkább elsőévesek } \\
\text { (rather freshmen) }\end{array}$ & $\begin{array}{l}\text { ** inkább felsóbb } \\
\text { évesek (rather older) }\end{array}$ & $\begin{array}{l}\text { nincs hatás } \\
\text { (not found) }\end{array}$ & $\begin{array}{l}\text { *** elsőévesek } \\
\text { legkevésbé (not } \\
\text { freshmen) }\end{array}$ & $\begin{array}{l}\text { **felsóbb } \\
\text { évesekre } \\
\text { legkevésbé } \\
\text { (not older } \\
\text { students) }\end{array}$ \\
\hline $\begin{array}{l}\text { Iskolatípus } \\
\text { (School type) }\end{array}$ & $\begin{array}{l}\text { ***szakiskolásokra és } \\
\text { szakközépiskolásokra } \\
\text { nagyon jellemzó } \\
\text { (rather secondary } \\
\text { and vocational } \\
\text { school students) }\end{array}$ & $\begin{array}{l}\text { ** szakiskolásokra } \\
\text { inkább jellemző } \\
\text { (rather vocational } \\
\text { students) }\end{array}$ & $\begin{array}{l}\text { nincs hatás } \\
\text { (not found) }\end{array}$ & $\begin{array}{l}\text { ***inkább } \\
\text { gimnazisták } \\
\text { (rather high } \\
\text { school students) }\end{array}$ & $\begin{array}{l}\text { nincs hatás } \\
\text { (not found) }\end{array}$ \\
\hline $\begin{array}{l}\text { Anya iskolai } \\
\text { végzettség } \\
\text { (Mother's } \\
\text { Eduaction) }\end{array}$ & $\begin{array}{l}\text { **alacsonyabb } \\
\text { iskolázottaknál } \\
\text { inkább (rather lower } \\
\text { educated) }\end{array}$ & $\begin{array}{l}\text { nincs hatás } \\
\text { (not found) }\end{array}$ & $\begin{array}{l}\text { nincs hatás } \\
\text { (not found) }\end{array}$ & $\begin{array}{l}\text { ***alacsonyan } \\
\text { iskolázottaknál } \\
\text { kevésbé } \\
\text { (not lower } \\
\text { educated) }\end{array}$ & $\begin{array}{l}\text { nincs hatás } \\
\text { (not found) }\end{array}$ \\
\hline $\begin{array}{l}\text { Apa iskolai } \\
\text { végzettség } \\
\text { (Father's } \\
\text { Education) }\end{array}$ & $\begin{array}{l}\text { nincs hatás } \\
\text { (not found) }\end{array}$ & $\begin{array}{l}\text { **inkább a legma- } \\
\text { gasabb és legalacso- } \\
\text { nyabb végzettségü- } \\
\text { eknél (rather lowest } \\
\text { and highest educated } \\
\text { parents) }\end{array}$ & $\begin{array}{l}\text { nincs hatás } \\
\text { (not found) }\end{array}$ & $\begin{array}{l}\text { **felsőfokú } \\
\text { iskolázottságnál } \\
\text { jellemző (rather } \\
\text { higher educated } \\
\text { parents) }\end{array}$ & $\begin{array}{l}\text { nincs hatás } \\
\text { (not found) }\end{array}$ \\
\hline $\begin{array}{l}\text { Családi szubjektív } \\
\text { jövedelem } \\
\text { (Family's } \\
\text { Subjective } \\
\text { Income) }\end{array}$ & $\begin{array}{l}\text { **legjobb anyagi } \\
\text { helyzetűekre } \\
\text { leginkább, a jó } \\
\text { anyagi helyzetüekre } \\
\text { legkevésbé jellemző } \\
\text { (most characteristic } \\
\text { for people with the } \\
\text { highest income and } \\
\text { least characteristic } \\
\text { for people with good } \\
\text { (higher than avera- } \\
\text { ge) income) }\end{array}$ & $\begin{array}{l}\text { nincs hatás } \\
\text { (not found) }\end{array}$ & $\begin{array}{l}\text { **legjobb anyagi } \\
\text { helyzetüekre } \\
\text { leginkább, a } \\
\text { rossz } \\
\text { helyzetúekre } \\
\text { legkevésbé } \\
\text { (rather the } \\
\text { highest income } \\
\text { group) }\end{array}$ & $\begin{array}{l}\text { nincs hatás } \\
\text { (not found) }\end{array}$ & $\begin{array}{l}\text { **özepes } \\
\text { vagy rossz } \\
\text { anyagi } \\
\text { helyezetűek- } \\
\text { re kevésbé } \\
\text { (enough or } \\
\text { low income) }\end{array}$ \\
\hline $\begin{array}{l}\text { Településtípus } \\
\text { (Settlement) }\end{array}$ & $\begin{array}{l}\text { ***2 ooo lakos } \\
\text { alatti települések, } \\
\text { megyei jogú városnál } \\
\text { legkevésbé (rather in } \\
\text { settlement with less } \\
\text { than } 2 \text { ooo residents) }\end{array}$ & $\begin{array}{l}\text { **inkább megyei } \\
\text { jogú város lakók, } \\
\text { legkevésbé } 2 \text { ooo } \\
\text { alatti települések } \\
\text { (least in settlements } \\
\text { with less than } 2 \text { ooo } \\
\text { people) }\end{array}$ & $\begin{array}{l}\text { nincs hatás } \\
\text { (not found) }\end{array}$ & $\begin{array}{l}\text { nincs hatás } \\
\text { (not found) }\end{array}$ & $\begin{array}{l}\text { nincs hatás } \\
\text { (not found) }\end{array}$ \\
\hline
\end{tabular}

$\mathrm{N}=$ 906, Módszer (Method): Varianciaanalízis - ANOVA vizsgálat, Szignifikanciaszintek (Sig.): ${ }^{* * *} \mathrm{p}<0,001{ }^{* *} \mathrm{p}<0,05$ nincs hatás (not found) $\mathrm{p}>0,05$ 


\subsection{A klaszterelemzés eredményei - \\ Results of the Cluster Analysis}

A klaszterek alapját adó faktorok megbízhatóságát már megvizsgáltuk (Cronbach Alfa>0,5), és minden faktort alkalmasnak találtunk a klaszterelemzésre (SZÉKELYI és BARNA, 2008). Célunk a diákok körében szegmentumok létrehozása, melyek között feltételeztük, hogy létezik egy fenntarthatóság és tudatos fogyasztás szempontjából pozitív attitűdökkel rendelkező csoport.

A klaszterezési eljárások közül hierarchikus (Ward-féle) módszert és nem hierarchikus elemzést is végeztünk (SZÉKELYI és BARNA,
2008). Végül a K-közép klaszterezés eredményeit választottuk a végleges szegmentumok kialakítására. Megvizsgáltuk a négy klaszter mintán belüli megoszlását és a faktorokkal való viszonyukat ANOVA vizsgálattal. A faktorok átlagértékei különböztek az egyes klaszterekben (2. ábra). Ezek után kereszttábla elemzéssel a háttérváltozók mentén is megvizsgálatuk az egyes klaszterekkel való összefüggésüket, ahol a nemet leszámítva minden jellemzővel szignifikáns összefüggést találtunk $\left(5_{a}\right.$ és $5_{b}$ táblázat). Összességében a négy klaszteres megoldás jól elkülönülő és jellemezhető szegmentumokat adott.

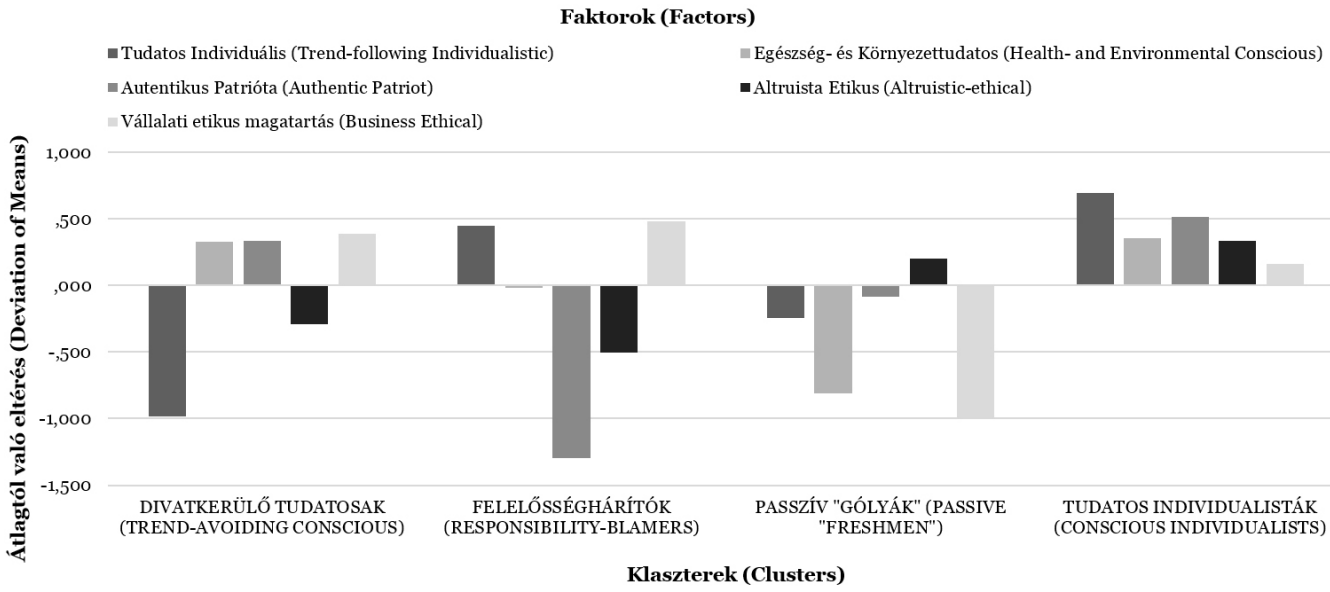

2. ÁBRA

\section{Klaszterek bemutatása a faktorok szerint (Comparison of Factors in Clusters)}

FIG. 2

Az első klaszterbe tartoznak a Divatkerülő tudatosak, akik a divattal, és az ehhez kapcsolódó individuális értékekkel egyáltalán nem akarnak azonosulni, viszont az egészség- és környezettudatosságot, valamint az autentikus értékeket magukénak érzik. Ôk inkább felsőbb éves gimnazisták, akik megfelelő, de nem a legjobb anyagi körülmények között élnek, és jellemző rájuk, hogy szüleik iskolai végzettsége a középiskolai végzettségnél magasabb.

A második klaszter tagjai csak az individuális és a vállalatok etikusságával kapcsolatos értékeket vallják magukénak. Ebből azt a következtetést vonhatjuk le, hogy ők nem érzik felelősnek magukat a környezetük és az egészségük alakításában, vagy ez számukra nem fontos, viszont elvárásként jelentkezik részükről a vállalatok felelősségvállalása, ezért is nevezhetjük őket Felelősséghárítóknak. Ök azok, akik az autentikus értékekkel - mint hagyományőrzés, hazai termékek preferálása - a legkevésbé azonosulnak. Háttérváltozók szerint hasonló arányban vannak köztük alsó- és felsőévesek, illetve különböző iskolázottságú szülők gyermekei.

A harmadik klaszterbe tartoznak a Paszszív „gólyák”. Náluk egyik értékcsoport iránti elkötelezettség sem jellemző. Alacsonyabban 
iskolázott szülők gyermekei és inkább kisebb településen rossz anyagi körülmények között élnek.

A negyedik csoport a Tudatos Individualisták csoportja, akik minden általunk vizsgált értékcsoporttal azonosulnak, azokat magukénak érzik. Náluk a legerősebb az első négy faktor jelenléte, de a vállalati etikusságot is szem előtt tartják. A szocio-demográfiai háttérváltozók alapján jellemző rájuk, hogy felsőbb évesek és gimnáziumba járnak az első klaszter tagjaihoz hasonlóan. Családjuk anyagi helyzetét tekintve ők élnek a legjobb anyagi körülmények között. A szüleik jellemzően felsőfokú végzettséggel rendelkeznek. A klasztert tovább bontottuk alklaszterekre, ám ebben az esetben nem találtunk lényeges eltéréseket azok tagjai között.

TABLE 5

A kialakított klaszterek bemutatása a szocio-demográfiai háttérváltozók mentén (Comparison of Socio-demographic Background Variables in Clusters)

\begin{tabular}{|c|c|c|c|c|c|c|}
\hline \multirow{2}{*}{\multicolumn{2}{|c|}{$\begin{array}{l}\text { Változók (Variables) } \\
\text { ek száma (Numbers of Clusters) }\end{array}$}} & \multicolumn{4}{|c|}{$\begin{array}{l}\text { Szocio-demográfiai jellemzők, } \\
\text { \% (Socio-demographic } \\
\text { Caracteristics, \%) }\end{array}$} & \multirow{3}{*}{$\begin{array}{l}\text { Szig. } \\
\text { (Sig.) }\end{array}$} \\
\hline & & 1. & 2. & 3. & 4. & \\
\hline \multicolumn{2}{|c|}{ Klaszterek mérete, \% (Cluster Size, \%) } & $\mathbf{2 5 , 5 9}$ & $\mathbf{1 7 , 9 7}$ & $\mathbf{2 3}, \mathbf{7 7}$ & 32,65 & \\
\hline \multirow{2}{*}{$\begin{array}{l}\text { Neme } \\
\text { (Gender) }\end{array}$} & Nő (Women) & 23,44 & 19,38 & 22,97 & 34,21 & \multirow{2}{*}{0,426} \\
\hline & Férfi (Men) & 27,89 & 17,23 & 23,58 & 31,29 & \\
\hline \multirow{4}{*}{$\begin{array}{l}\text { Kor } \\
\text { (Age) }\end{array}$} & $14-15$ & 27,32 & 18,03 & 25,68 & 28,96 & \multirow{4}{*}{0,024} \\
\hline & 16 & 23,30 & 15,34 & 32,95 & 28,41 & \\
\hline & 17 & 21,16 & 20,33 & 21,58 & 36,93 & \\
\hline & $18-19$ & 29,75 & 17,56 & 18,64 & 34,05 & \\
\hline \multirow{3}{*}{$\begin{array}{l}\text { Iskolatípus } \\
\text { (School Type) }\end{array}$} & Gimnázium (High school) & 30,35 & 18,74 & 13,65 & 37,27 & \multirow{3}{*}{$<0,001$} \\
\hline & Szakközépiskola (Secondary school) & 23,84 & 16,89 & 33,44 & 25,83 & \\
\hline & Szakiskola (Vocational School) & 4,76 & 17,86 & 47,62 & 29,76 & \\
\hline \multirow{5}{*}{$\begin{array}{l}\text { Évfolyam } \\
\text { (School Year) }\end{array}$} & 9. & 22,51 & 18,08 & 31,37 & 28,04 & \multirow{5}{*}{$<0,001$} \\
\hline & 10. & 22,41 & 14,37 & 32,76 & 30,46 & \\
\hline & 11. & 24,15 & 21,13 & 15,85 & 38,87 & \\
\hline & 12. & 34,48 & 15,17 & 15,86 & 34,48 & \\
\hline & 13. & 50,00 & 27,27 & 4,55 & 18,18 & \\
\hline \multirow{4}{*}{$\begin{array}{l}\text { Család } \\
\text { szubjektív } \\
\text { jövedelme } \\
\text { (Family's } \\
\text { Subjective } \\
\text { Income) }\end{array}$} & $\begin{array}{l}\text { Nagyon jól megélünk belőle, és még félre is } \\
\text { tudunk tenni (Can live on it very well and can } \\
\text { also save) }\end{array}$ & 19,10 & 17,71 & 22,57 & 40,63 & \multirow{4}{*}{0,001} \\
\hline & $\begin{array}{l}\text { Megélünk belőle, de keveset tudunk félretenni } \\
\text { (Can live on it, but can save little) }\end{array}$ & 29,77 & 18,21 & 20,81 & 31,21 & \\
\hline & $\begin{array}{l}\text { Elegendő, de félretenni már nem tudunk (Just } \\
\text { enough to live on, but cannot save) }\end{array}$ & 31,16 & 21,74 & 24,64 & 22,46 & \\
\hline & $\begin{array}{l}\text { Néha arra sem elég, hogy megéljünk belóle/ } \\
\text { Állandó anyagi problémákkal küzdünk } \\
\text { (Sometimes cannot make ends meet/ } \\
\text { Have regular financial problems) }\end{array}$ & 31,25 & 6,25 & 40,63 & 21,88 & \\
\hline
\end{tabular}


A kialakított klaszterek bemutatása a szocio-demográfiai háttérváltozók mentén (Comparison of Socio-demographic Background Variables in Clusters)

\begin{tabular}{|c|c|c|c|c|c|c|}
\hline \multirow{2}{*}{\multicolumn{2}{|c|}{$\begin{array}{c}\text { Változók (Variables) } \\
\text { Klaszterek száma (Numbers of Clusters) }\end{array}$}} & \multicolumn{4}{|c|}{$\begin{array}{c}\text { Szocio-demográfiai jellemzők, } \\
\text { \% (Social-demographic } \\
\text { Characteristics, \%) }\end{array}$} & \multirow{3}{*}{$\begin{array}{l}\text { Szig. } \\
\text { (Sig.) }\end{array}$} \\
\hline & & 1. & 2. & 3 . & 4. & \\
\hline \multicolumn{2}{|c|}{ Klaszterek mérete, \% (Cluster Size, \%) } & $\mathbf{2 5 , 5 9}$ & $\mathbf{1 7 , 9 7}$ & $\mathbf{2 3}, 77$ & 32,65 & \\
\hline \multirow{5}{*}{$\begin{array}{l}\text { Anya iskolai } \\
\text { végzettsége } \\
\text { (Mother's } \\
\text { Education) }\end{array}$} & Általános iskola (Primary School) & 17,47 & 23,30 & 36,89 & 22,33 & \multirow{5}{*}{$<0,00$} \\
\hline & $\begin{array}{l}\text { Szakközép- és szakiskola (Secondary and } \\
\text { Vocational School) }\end{array}$ & 26,34 & 14,51 & 27,95 & 31,18 & \\
\hline & Érettségi (High School Graduate) & 29,11 & 16,09 & 18,77 & 36,01 & \\
\hline & Felsőfokú (Higher Eduacation Graduate) & 27,75 & 20,53 & 15,96 & 35,74 & \\
\hline & Nem tudja (Not know) & 13,63 & 16,66 & 42,42 & 27,27 & \\
\hline \multirow{5}{*}{$\begin{array}{l}\text { Apa iskolai } \\
\text { végzettsége } \\
\text { (Father's } \\
\text { Education) }\end{array}$} & Általános iskola (Primary School) & 20,77 & 20,77 & 40,26 & 18,18 & \multirow{5}{*}{$<0,001$} \\
\hline & $\begin{array}{l}\text { Szakközép- és szakiskola (Secondary and } \\
\text { Vocational School) }\end{array}$ & 27,53 & 15,82 & 23,73 & 32,91 & \\
\hline & Érettségi (High School Graduate) & 30,27 & 18,37 & 19,46 & 31,89 & \\
\hline & Felsőfokú (Higher Eduacation Graduate) & 25,83 & 20,09 & 14,35 & 39,71 & \\
\hline & Nem tudja (Not know) & 13,04 & 17,39 & 40,22 & 29,35 & \\
\hline \multirow{3}{*}{$\begin{array}{l}\text { Településtípusa } \\
\text { (Settlement) }\end{array}$} & Megyei jogú város (County town) & 28,68 & 19,47 & 17,11 & 34,74 & \multirow{3}{*}{0,008} \\
\hline & $\begin{array}{l}2 \text { ooo fónél nagyobb település (Town with more } \\
\text { than } 2 \text { ooo residents) }\end{array}$ & 25,06 & 16,37 & 27,88 & 30,69 & \\
\hline & $\begin{array}{l}2000 \text { fónél kisebb település (Settlement with less } \\
\text { than } 2 \text { ooo residents) }\end{array}$ & 17,82 & 19,80 & 29,70 & 32,67 & \\
\hline
\end{tabular}

\section{KöVETKEZTETÉSEK ÉS}

\section{JAVASLATOK - CONCLUSIONS AND SUGGESTIONS}

Legfontosabb megállapításunk, hogy a középiskolások körében is megfigyelhetók azok a csoportok, amelyek az egyes fenntartható fejlődéshez kapcsolódó értékekkel azonosulnak.

A legtöbb kritika az önbevalláson alapuló kutatásokat azért éri, mert a valós cselekvést mérni csak korlátozottan képesek, mely jelen esetben is fennáll. Azonban látszik, hogy a Z generáció több mint felének fontosak az egészség- és környezetvédelemmel kapcsolatos, illetve a helyi értékek. Ez azt jelentheti, hogy a diákok jelentős része bevonható lehet a tudatos fogyasztói körbe, amennyiben megfeleló csatornán eljutnak hozzájuk a szükséges ismeretek, és lehetőségük van bizalmat kiépíteni a megfelelő termékekkel, szolgáltatásokkal. A fogyasztók jellemzően akkor vásárolnak „tudatosságot mutató” terméket, ha hisznek abban, hogy ezzel ténylegesen hozzájárulnak valamilyen környezeti vagy társadalmi kérdés megoldásához (KOVÁCS, 2013), és ez fokozottan igaz lehet erre az érzékeny, sok esetben szkeptikus korosztályra (SZÉKELY, 2013). Mivel ez a korosztály egy jól meghatározott helyen, az iskolában elérhetô, így fontos, hogy minden, a tudatos cselekvéshez szükséges információt megkapjanak. Minél jobban informált egy fogyasztó, annál nagyobb az esélye annak, hogy a tudatos alternatívát választja, ezenkívül fontosak a vállalati és kormányzati intézkedések is, melyek segítségével még nagyobb sokasághoz juthatnak el hasznos információk és a javasolt cselekvésmódok (LÁNG, 2003). A kutatásban megjelenő csoportok közül is azokat érdemes a különböző irányzatokhoz közelebb hozni, amelyek valamilyen formában már egy-egy tudatos tevékenységben vagy magatartásformában benne vannak. Számukra esetleg a célok lesznek ismeretlenek, viszont a cselekvési hajlandóság várhatóan sokkal nagyobb, mint társaik körében (SZMIGIN et al., 2009). Mivel a C ge- 
neráció tagjaihoz már elsősorban a „Mi”, azaz a többes szám első személyben megfogalmazott üzenetek jutnak el, így a nekik szánt marketingkommunikációs stratégiát érdemes a kutatási eredmények tükrében erre felépíteni. A cselekvési hajlandóság növelésére pedig olyan alkalmazásokat és mozgalmakat érdemes létrehozni, melyek nekik és róluk szólnak.

A négy különböző, feltárt csoport más és más kommunikációs stílusban érhető el. A Divatkerülő tudatosak szegmensének vizsgálata során önkéntes egyszerüségre hasonlító karaktert találtunk. Ez a mentalitás fakadhat a korosztály specialitásából, melyben a divat elutasítása, a különlegesség, az individuum előretörése a tanuló célja. Ez nem különbözik a korábbi generációktól. Viszont ebben a csoportban a trendek elleni lázadás mellett láthatjuk az általuk és a társadalom által közvetített értékek fontosságát, amelyek a hagyományok, az egészség, a természet. Ezt a csoportot leginkább a közös értékek és a különlegesség (a közösségen belül) üzenetével lehet elérni. Óket már nem kell meggyőzni a címben szereplő értékek fontosságáról, csupán napi rutinná tenni életükben ezek alkalmazását fogyasztói döntéseik meghozatalakor.

A második szegmens képezi azokat, akik másoktól várják a problémák megoldását. Saját felelősségüket az egészségük és a személyes környezetük kapcsán elhárítják, és csak önkifejezésüket érzik hangsúlyosnak. A Passzív „gólyák" kapcsán az érdektelenséget és a tudatos cselekvéstől való elfordulást láthattuk. Mind a második, mind a harmadik szegmens esetében a legcélravezetőbb saját felelősségük bemutatása, illetve megerősítése lenne. Ez a két csoport jellemzően alsóbb évfolyamokon tanul, így az iskolai oktatás keretében is több idő van a bevonásukra.

A Tudatos Individualisták azok, akik elvi szinten a leginkább magukénak érzik a LOHAS csoport értékeit. Náluk is az értékek elmélyítése és a napi rutinba való beemelése lenne a cél. Mivel ők elfogadják és követik a napi divatot és életstílus trendeket, feléjük mindenképp az ezekre építő kommunikáció lehet célravezető (például: mainstream média, zene, ruházat).

\section{IRODALOMJEGYZÉK - REFERENCES}

Ádám F.: Fenntartható fogyasztás családi és iskolai közösségekben. In: Nyitrainé N. I. - Varga A. (szerk.): Bibó boci bóklászása és más ötletek a fenntarthatóságra neveléshez. Magyar Környezeti Nevelési Egyesület, Budapest, 2001.

Bagdy E.: Hogyan lehetnénk boldogabbak? Kulcslyuk Kiadó, Budapest, 2010.

Barnett, C.: Governing the Subjects and Spaces of Ethical Consumption: Full Research Report. ESRC End of Award Report, RES-143-25-0022-A. ESRC, Swindon, 2007.

Bassiouni, D. - Hackley, C.: Generation Z Children's Adaptation to Digital Consumer Culture: A Critical Lierature Review. Journal of Customer Behaviour. 2014. 13 (2) $113-133$.

Benn, J.: Consumer Education between Consumership and Citizenship: Experiences from Studies of Young People. International Journal of Consumer Studies. 2004. 28 (2) 108-116.

Boyes, E. - Skamp, K. - Stanisstreet, M.: Australian Secondary Students Views About Global Warming: Beliefs About Actions and Willingness to Act. Research in Science Education. 2008. 39 (5) 661680.

Brown, L. T.: Building a Sustainable Society. W. W. Norton \& Co. Inc. 1981.

Caru, A. - Cova, B.: Revisiting the Consumption Experience: a More humble but Complete View of the Concept. Marketing Theory. 2003. 3 (2) 267-286.

Csete M.: Regionális és környezetgazdaságtan. Edutus Főikola, Budapest, 2012.

Dudás K.: A tudatos fogyasztói magatartás dimenziói. Vezetéstudomány. 2011. 42 (78) $47-56$.

ENSZ: Draft outcome document of the United Nations summit for the adoption of the post-2015 development agenda. 2015. http://www.un.org/en/ga/search/view_ doc.asp?symbol=A/69/L.85 (Letöltés dátuma: 2016. júl. 7.) 
Farkas T.: A fenntartható fejlődés új ENSZprogramja. MENSZT Fenntartható fejlődési célok. 2015. http://www.menszt. hu/tudnivalok_az_egyesult_nemzetek_ szervezeterol/fenntarthato_fejlodesi_ celok (Letöltés dátuma: 2016. nov. 11.)

Fintor G. J.: Az egészségtudatosság megjelenése nyíregyházi felső tagozatos diákoknál. In: Kozma T. - Kiss V. Á. Jancsák Cs. - Kéri K.: HERA Évkönyv 2014. Tanárképzés és oktatáskutatás. Magyar Nevelés- és Oktatáskutató Egyesület, 2015.

Fényes H.: Önkéntesség és új típusú önkéntesség a felsőoktatási hallgatók körében. DUPress, Debrecen, 2016.

Fleischer T.: Fenntartható fejlődés: környezeti, társadalmi és gazdasági tényezők. In: Magyarország globális környezete 2020-ig. Háttértanulmányok a magyar külstratégiához (1). MTA Világgazdasági Kutatóintézet - CEU Center for EU Enlargement Studies, Budapest, 2007.

Frantz, J. - Chandeu, M.: School-based Interventions on Physical Inactivity as Risk Factor of Chronic Diseases of Lifestyles: A Review. African Journal for Physical Health Education. Recreation and Dance, 2011. June, 49-48.

Füzesi Zs. - Varga J.: Egészség- és betegség-koncepciók. In.: TÁMOP4.1.2.A/1-11/1-2011-0094 (szerk.): Emberi folyamatok idegi szabályozása - $a$ neurontól a viselkedésig. Pécsi Tudományegyetem, Dialóg Campus Kiadó-Nordex Kft., 2014.

Füzesi Zs. - Tistyán L.: A környezeti tudat alakulásának elemzése a rendszerváltás óta eltelt időszakban. Zöld Belépő, 1998. 54 .

Gaál Sz. - Szigeti P. - Dimitra, P. - Matthew, G - Ewout van, G.: Major Challenges Ahead for Hungarian Healthcare. British Medical Journal. 2011. (December) 343.
GFK - TÁRKI Egészséggazdasági Monitor: Egyre többet költenek a magyarok egészségükre. 2012. http:// www.gfk.hu/pressreleases/press releases/articles/o10199/index.hu.ht $\mathrm{ml}$ 2012. (Letöltés dátuma: 2012. nov. 20.)

Gulyás E.: Az etikus fogyasztás mint a közügyekben való részvétel. Politikatudományi Szemle. 2007. 14 (4) 111-126.

Hofmeister-Tóth Á. - Kelemen K. Piskóti M.: A fenntartható fogyasztás jellemzői és trendjei Magyarországon és a régióban. In: Csutora M. - HofmeisterTóth Á. (szerk.): Fenntartható fogyasztás? Aula Kiadó, Budapest, 2011.

Jin, Z. - Lynch, R. - Attia, S. Chansarkar, B. - Gülsoy, T. Lapoule, P. - Liu, X. - Newburry, W. - Nooraini M. S. - Parente, R. - Purani, K. - Ungerer, M.: The Relationship between Consumer Ethnocentrism, Cosmopolitanism and Product Country Image Among Younger Generation Consumers: The Moderating Role of Country Developement Status. International Business Review. 2015. 24 (3) 380-293.

Kaló Z.: Versenyképes gyógyszerpolitika. IME. 2007. 6 (10) 25-31.

Kelemen Z.: A magyar fogyasztói attitűd az előnyalapú saját márkákkal szemben. In: Új marketing világrend MOK 16. országos konferenciája. 2010. augusztus 26-27., Budapesti Kommunikációs és Üzleti Főiskola, Budapest.

Kerekes S.: A fenntartható fejlődés közgazdasági értelemzése. In. Bulla M. - Tamás P. (szerk.): Fenntartható fejlődés Magyarországon - Jövőképek és forgatókönyvek. Új Mandátum Kiadó, Budapest, 2006.

Kerk Van de, G. - Manuel, A.: A Comprehensive Index for a Sustainable Society: The SSI - the Sustainable Society Index. Ecological Economics. 2008. 66 228-242. 
Kietzmann, J. H. - Angell, I.: Generation C: Creative Consumers in a World of Intellectual Property Rights. International Journal of Technology Marketing. 2014. 9 (1) 86-98.

Kiss V. Á. - Szakály Z.: A fiatalok egészségtudatossága a táplálkozási szokásaikat illetően. In: Bíró-Szigeti Sz. et al. (szerk.): Marketing hálózaton innen és túl: Az Egyesület a Marketing Oktatásért és Kutatásért XXI. Országos konferenciájának tanulmánykötete. Budapest, BME Menedzsment és Vállalatgazdaságtan Tanszék, 2015. 145154.

Kiss V. Á.: A fenntarthatóbb fogyasztói magatartás és megnyilvánulási formái. TAYLOR Gazdálkodás- és szervezéstudományi folyóirat. 2015. 7 (3-4) 313-324.

Kocsis T.: A materializmustól a teljes emberig. Kovász. 2001. (ősz-tél) 101-136.

Kovács I.: Társadalmilag felelős fogyasztás vizsgálata. Területi statisztika. 2013. 53 (4) $372-386$.

Kreeb, M. - Motzer, M. - Schulz, W. F.: LOHAS als Trendsetter für das Nachhaltigkeitsmarketing. In: C. Schwender, C. - Schulz, W. - Kreeb, M. (eds.): Medialisierung der Nachhaltigkeit. Das Forschungsprojekt balance(f): Emotionen und Ecotainment in den Massenmedien. Metropolis, Marburg, 2008. 303-314.

Kriston P. - Pikó B.: Serdülőkorú fiatalok rizikómagatartásának elemzése önminősített egészségi állapotukkal összefüggésben. Népegészségügy. 2016. 94 (1) 22-32.

KSH: Európai lakossági egészségfelmérés. 2014. Statisztikai Tükör. 2015. (29) 1-8.

Láng I.: Stockholm - Rió - Johannesburg. Lesz-eújanapalattakörnyezetvédelemben? Magyar Tudomány. 2001. (12) 1415-1422.

Láng I.: A fenntartható fejlődés Johannesburg után. Agrinform Kiadó, Budapest, 2003.
Lehota J. - Csíkné Mácsai É. - Rácz G.: $\mathrm{Az}$ egészségtudatos élelmiszer-fogyasztói magatartás értelmezése a LOHAS koncepció alapján. Táplálkozásmarketing . 2014. 1 (1-2) 38-48.

Malota E.: Fogyasztói Etnocentrizmus. Doktori értekezés, Budapesti Közgazdaságtudományi és Államigazgatási Egyetem, Budapest, 2003.

Málovics Gy. - Bajmócy Z.: A fenntarthatóság közgazdaságtani értelmezései. Közgazdasági Szemle. 2009. 56 (május) 464-483.

Marjainé Sz. Zs. - Zsóka Á. - Széchy A.: A Budapesti Corvinus Egyetem hallgatóinak fogyasztási szokásai a fenntarhatóság szemszögéből. In: Sikos T. T. (szerk): Fenntartható fogyasztás és növekedés határai: Új trendek a kereskedelemben. Selye János Egyetem Kutatóintézete, Gödöllő-Komárom, 2010. 145-164.

Marjainé Széchy Zs. - Zsóka Á. Széchy A.: Környezettudatosak-e a középiskolások? In: Kerekes S. - Csutora M. (szerk.): Fenntartható fogyasztás? Trendek és lehetőségek Magyarországon. AULA Kiadó, Budapest, 2012a. 225-258.

Marjainé Szerényi Zs. - Zsóka Á. - Kocsis T. - Széchy A.: A fiatalok fogyasztási és életmódbeli szokásai a környzeti nevelés tükrében. Új Pedagógiai Szemle. 2012b. 62 (11-12) 15-36.

McGinnis, J. M. - Williams-Russo, P. - Knickman, J. R.: The Case for More Active Policy Attention to Health Promotion. Health Affairs. 2002. 21 (2) 78-93.

MENSZT: Tudnivalók az Egyesült Nemzetek Szervezetéröl. 2015. http://www.menszt. hu/tudnivalok_az_egyesult_nemzetek_ szervezeterol/fenntarthato_fejlodesi_ celok (Letöltés dátuma: 2016. júl. 7.)

Michalos, A. C. - Creech, H. - McDonald, C. - Kahlke, P. M. H.: Measuring Knowledge, Attitudes and Behavoiurs Towards Sustainable Developement. International Institute for Sustainable Developement, Winnipeg, 2009. 
Nagy Sz.: Fenntartható fogyasztás. Nemzeti Tankönyv Kiadó, Budapest, 2011.

Neira, M. - Gore, F. - Brune, M. N. - Hudson, T. - Garbino, J. P. de: Environmental Threats to Children's Health - A Global Problem. International Journal of Environment and Health. 2008. 2 (3-4) 276-292.

Nielsen: Introducing Gen C: The Connected Collective Consumer. 2010. http://www. nielsen.com/us/en/insights/news/2010/ introducing-gen-c-the-connected-collectiveconsumer.html (Letöltés dátuma: 2015. ápr. 4.)

Pikó B.: Magatartástudomány és prevenció. A preventív magatartásorvoslás jelentősége. Magyar Tudomány. 2003. (11) 1381.

Pikó B.: Szabadidő és életmód a fiatalok körében. In: Pikó B. (szerk.): Ifjúság, káros szenvedélyek és egészség a modern társadalomban. L'Harmattan Kiadó, Budapest, 2005. 30-40.

Pintér A.: Útmutató és táblázatok a gyermekkori tápláltság megítéléséhez. Országos Gyermekegészségügyi Intézet (OGYEI, 2003), a Magyar Védőnők Egyesülete (MAVE, 1991). 2004. 13-14

Prensky, M.: Digital Natives, Digital Immigrants Part 1. On the Horizon. $M C B$ University Press Ltd. 2001. 9 (5) 1-6.

Rácz G. - Horváth Á.: Lohas Themes in Hungarian Women's Magazine. Regional and Business Studies. 2011. 3 (1) 589-606.

Rácz G.: Az értékek változásának és a fenntartható fejlődés trendjének hatása a hazai élelmiszerfogyasztásra. Doktori értekezés. Szent István Egyetem, Gazdálkodás- és Szervezéstudományok Doktori Iskola, Gödöllő, 2013.

Slater, D. - Miller, D.: Moments and Movements in the Study of Consumer Culture: A Discussion between Daniel Miller and Don Slater. Journal of Consumer Culture. 2007. 7 (1) 5-23.

Somlai P.: Nemzedéki konfliktusok és kötelékek. In: Bauer B. - Szabó A. (szerk.): Arctalan nemzedék. Nemzeti Család- és Szociálpolitika Intézet, Budapest, 2011. 25-36.
Soron, D.: Sustainability, Self-identity and the Sociology of Consumption. Sustainable Development Special Issue: Sustainability and Identity. 2010. 18 (3) 172-181.

Spurrier, N. J. - Magarey, A. A. Golley, R. - Curnow, F. - Sawyer, M. G.: Relationships between the Home Environment and Physical Activity and Dietary Patterns of Preschool Children: A Cross-sectional Study. International Journal of Behavioral Nutrition and Physical Activity. 2008. (5) 31-43.

Szabó E.: Az eredet- és minőségjelzők alkalmazásának lehetőségei és feltételei a marketingkommunikációban. Doktori értekezés. Budapesti Corvinus Egyetem, Budapest, 2006.

Szakály Z.: Hagyományos magyar termékek piaci lehetőségeinek elemzése. Élelmiszer, Táplálkozás és Marketing. 2008. 5 (2-3) 57-65.

Szakály Z. - Petô K. - Popp J. - Jasák H.: A fenntartható fogyasztás iránt elkötelezett fogyasztói csoport, a LOHAS szegmens jellemzői. Táplálkozásmarketing. 2015. 2 (1) 3-9.

Székely L.: Az új csendes generáció. In.: Székely L. (szerk.): Magyar Ifjúság 2012. Magyar Közlöny Lap- és Könyvkiadó. Budapest, 2013. 9-28.

Székelyi M. - Barna I.: Túlélőkészlet az SPSS-hez. Typotex Kiadó Kft., Budapest, 2008.

Szlávik J.: A fenntarthatóság szintjei és útjai (A fenntartható fejlődés közgazdasági összefüggései.) Akadémiai nagydoktori thesis. MTA, Budapest, 2002.

Szlávik J.: Lépések a fenntartható gazdálkodás irányába: Gondolatok Láng István és Kerekes Sándor: Megalakult a Túlélés Szellemi Kör címü vitairatához. Magyar Tudomány. 2014. (1) 99-108.

Szmigin, I. - Carrigan, M. - McEachern, M. G.: The Conscious Consumer: Taking a Flexible Approach to Ethical Behaviour. International Journal of Consumer Studies. 2009. 33 (2) 224-231. 
Tóbi I.: A fiatalok fogyasztása, tartalomfogyasztása. In: Tudománykommunikáció Z generációnak (TÁMOP projektvezető: Törőcsik M.) Pécsi Tudományegyetem, Pécs, 2013. 2-59.

Töröcsik, M.: Fogyasztói magatartás trendek. KJK-Kerszöv Jogi és Üzleti Kiadó Kft., Budapest, 2003.

Törőcsik M.: A tudatos fogyasztást és egészséget preferáló új fogyasztói trendcsoport, a LOHAS csoport megjelenése Magyarországon. Élelmiszer, Táplálkozás és Marketing. 2007. (1) 4147.

Törőcsik, M. - Dudás K.: Environmental Conscious Consumer Clusters in Hungary. Competitiveness and European Integration International Conference, Cluj-Napoca, Romania, October 26-27. 2007.

Valkó L.: Fenntartható/környezetbarát fogyasztás és a magyar lakosság környezeti tudata (18.) Aula Kiadó, Budapest, 2003.
Vaskovics L.: A posztadoleszcencia szociológiai elmélete. Szociológiai Szemle. 2000. 20 (4) 3-20.

Vitrai J. - Vokó Z.: Egészségmodell. In: Népegészségügyi Jelentés (szakértőknek). Budapest, Johan Béla Országos Epidemiológiai Központ, 2006.

Zsiros E. - Örkényi Á. - Költő A. Kertész K. - Kökönyei Gy. - Németh Á.: Serdülőkorú fiatalok mentális egészségének alakulása Magyarországon 2002-201O között: Az Iskoláskorú Gyermekek Egészségmagatartása (HBSC) kutatás adatainak trendelemzése. Budapest, 2012.

Zsóka Á. - Marjainé Szerényi Zs. Széchy A.: A környezeti nevelés szerepe a fenntartható fogyasztás és életmód kialakításában. In: Fenntartható fogyasztás? A fenntartható fogyasztás gazdasági kérdései. Budapesti Corvinus Egyetem, Budapest, 2011. 90-109.

WHO: Definition of Health. 1946. http:// www.who.int/about/definition/en/print. html (Letöltés dátuma: 2014. okt. 10.)

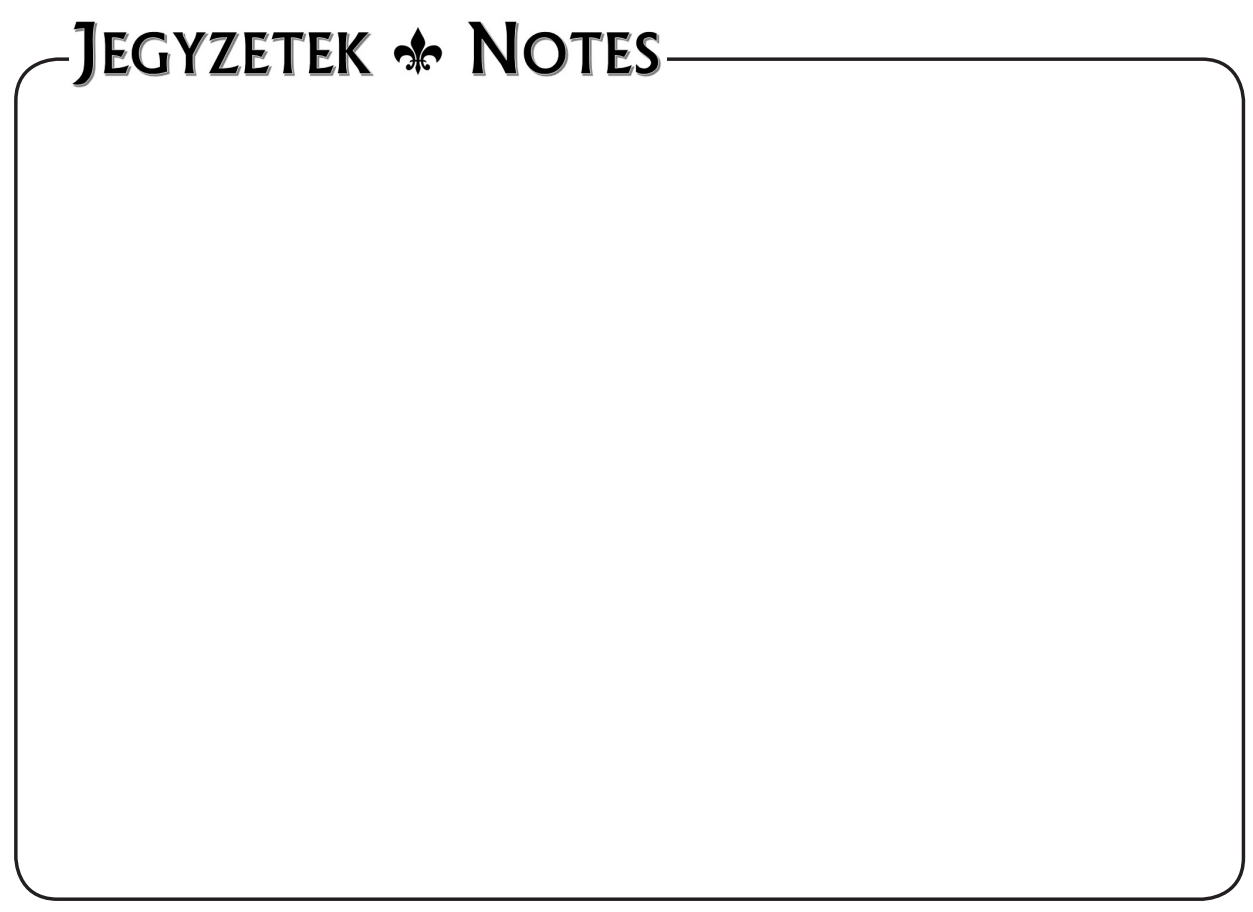

